\title{
Adsorption of Anionic Dye on the Acid-Functionalized Bentonite
}

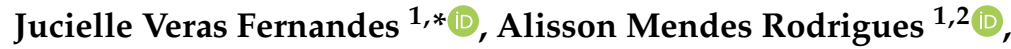 \\ Romualdo Rodrigues Menezes $1,2(1)$ and Gelmires de Araújo Neves ${ }^{1,2}$ (1) \\ 1 Programa de Pós-Graduação em Ciência e Engenharia de Materiais (PPG-CEMat), Universidade Federal de \\ Campina Grande, Av. Aprígio Veloso-882, Bodocongó, Campina Grande-PB 58429-900, Brazil; \\ alisson.mendes@professor.ufcg.edu.br (A.M.R.); romualdo.menezes@ufcg.edu.br (R.R.M.); \\ gelmires.neves@ufcg.edu.br (G.d.A.N.) \\ 2 Unidade Acadêmica de Engenharia de Materiais, Centro de Ciência e Tecnologia, Universidade Federal de \\ Campina Grande, Av. Aprígio Veloso-882, Bodocongó, Campina Grande-PB 58429-900, Brazil \\ * Correspondence: jucielle_fernandes@hotmail.com
}

Received: 29 May 2020; Accepted: 10 July 2020; Published: 14 August 2020

\begin{abstract}
The efficiency of acid treatment on natural calcium bentonite (natural bentonite) for anionic dye adsorption was investigated using methyl orange (MO) as a probe. Additionally, adsorption experiments were accomplished between the natural bentonite, acidified bentonite, and a cationic dye (methylene blue, MB). Acid functionalization in natural bentonite (RF) was carried out with $\mathrm{HCl}$ and $\mathrm{H}_{2} \mathrm{SO}_{4}$ acids (RF1 and RF2, respectively). The samples were characterized by chemical analysis, mineralogy, particle size, and thermal behavior with the associated mass losses. The adsorption efficiency of MO and MB dyes was investigated by the effects of the initial concentration of adsorbate $\left(C_{i}\right)$ and the contact time $\left(t_{c}\right)$. The acid treatment was efficient for increasing the adsorption capacity of the anionic dye, and the $Q_{\max }^{\text {exp }}$ values measured were $2.2 \mathrm{mg} / \mathrm{g}$, $67.4 \mathrm{mg} / \mathrm{g}$ e $47.8 \mathrm{mg} / \mathrm{g}$ to RF, RF1 e RF2, respectively. On the other hand, the acid functionalization of bentonite did not significantly modify the MB dye adsorption. The Sips equation was the best fit for the adsorption isotherms. Thus, we found that the acid-functionalized bentonite increases the anionic dye adsorption by up to $8000 \%$. The increased adsorptive capacity of acidified bentonite was explained in terms of electrostatic attraction between the clay surface and the dye molecule.
\end{abstract}

Keywords: bentonite; methylene blue; methyl orange; acid functionalization; adsorptive capacity

\section{Introduction}

Synthetic dyes are polluting agents with complex, non-biodegradable chemical structures that cause harmful effects both for the aquatic life and for human beings [1]. These dyes can be classified as anionic, cationic, and non-ionic [2]. Anionic dyes, when in aqueous solution, have a negative charge, such as those of sulfonate groups $\left(\mathrm{SO}^{3-}\right)$. In turn, the cationic dyes (due to chemical groups such as the amine or sulfur) have a net positive charge [3]. The methyl orange dye (anionic dye) has high toxicity, a mutagenic and carcinogenic nature [4], a hard-breaking molecular structure [5], and difficult adsorption in different materials. On the other hand, methylene blue (cationic dye) does not have high toxicity but may cause harmful effects on human health, such as vomiting, increased heart rate, diarrhea, and cyanosis [6]. Disposing of both dyes in wastewaters in streams and aquifers may hamper reoxygenation and prevent aquatic life photosynthesis [7-9].

The removal of such dyes from wastewaters is often conducted via membrane filtration, ion-exchange separation, degradation, flotation, chemical oxidation, electrochemical treatment, adsorption [10-13]. Among these processes, adsorption shows more significant economic potential for 
removing dyes due to its efficiency, low energy consumption, and easy operation [14,15]. Different types of adsorbents can be used to remove contaminants, such as activated charcoal [16-19], polymeric [20-23], and biological materials [24-28]. These adsorbents have a high capacity for removing dyes, but their high cost and low capacity for reuse restrict their use [29]. Therefore, the search for low-cost adsorbents, such as clay minerals, has been extensively studied [30].

From the literature, it is possible to find several studies about the MO dye sorption in different adsorbents. Among them, the study published by Sabarish and Unnikrishnan stands out [31], wherein the zeolite hybrid matrix membranes (PVA/PDADMAC/ZSM-5) were used, and the $Q_{\max }^{\text {exp }}$ obtained was equal to $76.4 \mathrm{mg} / \mathrm{g}$. The zeolite incorporation in the PVA/PDADMAC/ZSM-5 makes the membrane surface heterogeneous, promoting this material as an alternative for removing MO from industrial streams. Robati et al. [31] used graphene oxide as an adsorbent for $\mathrm{MO}$ dye adsorption, and the amount adsorbed was equal to $16.83 \mathrm{mg} / \mathrm{g}$, in a contact time of $100 \mathrm{~min}$ at $\mathrm{pH}=3$. Ji et al. [32] evaluated the methyl orange adsorption in organo-vermiculites modified by an asymmetric Gemini surfactant and concluded that the higher amount of modifier implies greater availability of surfactant. In this case, the higher MO dye adsorption measured was equal to $132.03 \mathrm{mg} / \mathrm{g}$. Additionally, it is possible to find published studies about methylene blue in different solvents. Şahin et al. [33] modified the surface of bentonite clay with plasma to improve its adsorptive capacity for MB. Indeed, the plasma treatment increased the adsorptive capacity of bentonite, and the highest value obtained was equal to $303 \mathrm{mg} / \mathrm{g}$. On the other hand, Sellaoui et al. [34] investigated the MB adsorption mechanism on Brazilian berries seeds. Therefore, studies of the $\mathrm{MO}$ and MB adsorption in bentonite as an adsorbent are plentiful in the literature. However, few studies are addressed to investigate the adsorption of the anionic dye in acidified calcium bentonites.

On the other hand, the smectites are abundant clay minerals and have a high degree of isomorphic substitutions that generate a deficiency of positive charge and a high capacity of electrostatic interaction [35]. Besides being considered a low-cost adsorbent, it is also easily available, eco-friendly, non-toxic, and has a large surface area, cation exchange capacity, high porosity, and active sites in its surface [36-38], which gives it dye adsorption capacity. However, its deficiency of positive charge impairs the adsorption of anionic dyes, even in environments with acid $\mathrm{pHs}$, hampering its applicability in the treatment of waters contaminated with such dyes.

The adsorption mechanism of the calcium bentonites, clays formed by the smectite clay mineral montmorillonite, occurs mainly due to ionic exchanges and electrostatic interactions in the surface of the clay mineral particles [39]. The permanent high negative charge in the clay surface is characteristic of the montmorillonite, which can facilitate adsorption by cationic dyes and impair that of anionic ones [40-42]. Thus, changes in the clay structure can be performed to improve the capacity of the adsorption of anionic dyes. The acid treatment shows to be an efficient and low-cost alternative [43] to enhance clay porosity and surface properties [44].

In this respect, this study aims at investigating the efficiency of the acid treatment in Brazilian calcium bentonite from the state of Paraiba for adsorption of the anionic dye methyl orange. The bentonite clay was modified with acids $\left(\mathrm{HCl}\right.$ and $\left.\mathrm{H}_{2} \mathrm{SO}_{4}\right)$, characterized, and had its adsorption capacity evaluated by adsorption tests.

\section{Materials and Methods}

\subsection{Raw Materials}

The calcium bentonite used in this paper derived from the city of Sossego, located in the state of Paraiba-Brazil. The other reagents used were hydrochloric acid P.A (Nuclear), MM: $36.5 \mathrm{~g} / \mathrm{mol}$ and purity 40\%, sulfuric acid P.A (Química Moderna, Barueri-SP, Brazil), MM: $98.08 \mathrm{~g} / \mathrm{mol}$ and purity 98\%, methylene blue P.A (Synth), and methyl orange P.A (NEON). 


\subsection{Acid-Functionalization of Bentonite}

Under constant stirring and temperature $\left(90^{\circ} \mathrm{C}\right), 25 \mathrm{~g}$ of clay were immersed in $250 \mathrm{~mL}$ of solutions of the $\mathrm{HCl}(13.04 \mathrm{~mol} / \mathrm{L})$ and $\mathrm{H}_{2} \mathrm{SO}_{4}(18.38 \mathrm{~mol} / \mathrm{L})(4 \mathrm{~N})$, in a reflux system. After $2 \mathrm{~h}$, the system was filtered, and the solid was washed repeatedly with distilled water, and then filtered again under vacuum. The filtrate obtained was dried for $48 \mathrm{~h}$ at $60{ }^{\circ} \mathrm{C}$ [45]. The clays without acid attack were identified as RF, and those activated in acid solutions of $\mathrm{HCl}$ and $\mathrm{H}_{2} \mathrm{SO}_{4}$ were identified as RF1 and $\mathrm{RF} 2$, respectively.

\subsection{Characterization}

The chemical analysis was determined via X-ray fluorescence (Shimadzu, EDX720, Kyoto, Japan). $X$-ray diffraction was performed using a Shimadzu XRD6000 $(\mathrm{CuK} \alpha, 40 \mathrm{kV} / 30 \mathrm{~mA})$. All the experiments were performed at room temperature, with a goniometer speed of $2^{\circ} / \mathrm{min}$, an angular step of 0.02 , and a counting time $0.6 \mathrm{~s}$ [46-48]. The granulometric analysis was performed by low-angle laser light scattering (Cilas, 1064LD, Orléans, France), where the clays were scattered in $250 \mathrm{~mL}$ of distilled water in a Hamilton Beach N5000 stirrer at a speed of 17,000 rpm for $10 \mathrm{~min}$; then, the scatterings were inserted in the equipment in wet mode until they reached the optimal concentration of 150 units of diffraction/incidence area [49,50]. The experiments of differential thermal analysis (BP engineering) and thermal gravimetry (DTG-60H Simultaneous DTA-TG Apparatus Shimadzu) were performed under the air atmosphere using alumina crucibles. All the samples were heated at $12.5^{\circ} \mathrm{C} / \mathrm{min}$ from room temperature to $1000^{\circ} \mathrm{C}$ [51].

\subsection{Adsorption Experiments}

Solutions of $200 \mathrm{~mL}$ containing the dyes methyl orange (MO) and methylene blue (MB) were prepared in pre-defined concentrations $(25,50,75,100,125,150,200,250,300,350,400 \mathrm{mg} / \mathrm{L}$ for MO; and $25,50,75,100,125,150,200,250 \mathrm{mg} / \mathrm{L}$ for MB). For each solution, $100 \mathrm{mg}$ of the RF, RF1 and RF2 clays were added. The adsorption of $\mathrm{MO}$ and $\mathrm{MB}$ was conducted in aqueous solution keeping the $\mathrm{pH}=6$, steering of $300 \mathrm{rpm}$, and temperature $\left(24^{\circ} \mathrm{C}\right)$ constant. The parameters contact time (for MB: 5 , 10,15, 30, 45, 60, 90,120 min; and for MO: 15, 30, 45, 60, 90, 120, $180 \mathrm{~min}$ ) and initial concentration of adsorbate ( 25 to $400 \mathrm{mg} / \mathrm{L}$ for $\mathrm{MO}$, and 25 to $250 \mathrm{mg} / \mathrm{L}$ for $\mathrm{MB}$ ) were investigated.

For each time point studied, $10 \mathrm{~mL}$ of solution (clays + dyes) were centrifugated ( $3600 \mathrm{rpm}$ for $5 \mathrm{~min}$ ). The solutions were analyzed by UV-VIS spectroscopy (Shimadzu, model UV-1800). The amounts adsorbed by adsorbent mass were evaluated via Equation (1):

$$
Q=\frac{\left(C_{i}-C_{e}\right) \cdot V}{m}
$$

where $V$ is the solution volume (L), $\mathrm{m}$ is the adsorbent mass $(\mathrm{g}), C_{i}$ and $C_{e}$ are the initial and equilibrium concentrations $(\mathrm{mg} / \mathrm{L})$, respectively.

\subsection{Isothermal and Kinetic Studies}

The Langmuir [52] (Equation (2)), Freundlich [53] (Equation (3)), Dubinin-Astakhov (D-A) [54] (Equation (4)), Dubinin-Radushkevich (D-R) [55] (Equation (5)), and Sips [30] (Equation (6)) equations were adjusted to the adsorption isotherms to infer surface properties of the natural and acidified bentonite with anionic and cationic dyes. The equations of the isothermic models mentioned are summarized below:

$$
\begin{gathered}
Q_{e L}=\frac{Q_{\max }^{c a l} \cdot K_{L} \cdot C_{e}}{1+K_{L} \cdot C_{e}} \\
Q_{e F}=K_{F} \cdot(C e)^{\frac{1}{n_{F}}} \\
Q_{e D A}=Q_{\max }^{c a l} \exp \left[-\left(\frac{R \operatorname{Rln}\left(C_{S} / C_{e}\right)}{E_{D A}}\right)^{n_{D A}}\right]
\end{gathered}
$$




$$
\begin{gathered}
Q_{e D R}=Q_{\max }^{c a l} \exp \left[-\left(\frac{R T \ln \left(C_{s} / C_{e}\right)}{E_{D R}}\right)^{2}\right] \\
Q_{e S I P S}=\frac{Q_{\max }^{c a l} K_{S} C_{e}^{n S}}{1+K_{S} C_{e}^{n S}}
\end{gathered}
$$

where for the Langmuir equation, $Q_{\max }^{c a l}(\mathrm{mg} / \mathrm{g})$ is the maximum adsorption capacity, $C_{e}(\mathrm{mg} / \mathrm{g})$ is the equilibrium concentration, and $K_{L}(\mathrm{~L} / \mathrm{mg})$ is the Langmuir constant. In the Freundlich equation, $K_{F}\left(\mathrm{mg}^{1-(1 / n)} \mathrm{g}^{-1} \mathrm{~L}^{1 / n}\right)$ is the Freundlich adsorption capacity constant, and $\mathrm{n}_{\mathrm{F}}$ is an empirical constant indicating adsorption intensity. In the D-A and D-R models, $Q_{m a x}^{c a l}$ has the same meaning as that observed in the Langmuir equation, $n_{D A}$ is the adjustment parameter proposed by Dubinin-Astakhov, $\varepsilon(\mathrm{KJ} / \mathrm{mol})$ is the potential for adsorption, and $E_{D A}(\mathrm{KJ} / \mathrm{mol})$ is the characteristic energy of the system. $C_{S}$ and $C_{e}$ are solubility and equilibrium concentration, respectively. $E_{D R}(\mathrm{KJ} / \mathrm{mol})$ is the parameter for estimating the free energy of the system. In Equation (6), $K_{S}$ is the Sips isothermal constant $(\mathrm{L} / \mathrm{mmol})$, and $n_{S}$ indicates the system heterogeneity.

The pseudo-first-order [56] and pseudo-second-order models [57] were used to infer adsorption kinetics between the MB and MO dyes and RF, RF1 and RF2 clays, see Equations (7) and (8):

$$
\begin{gathered}
Q_{t P F O}=Q_{e}\left(1-e^{-K_{1} \cdot t}\right) \\
Q_{t P S O}=\frac{K_{2} \cdot Q_{e}^{2} \cdot t}{1+K_{2} \cdot Q_{e} \cdot t}
\end{gathered}
$$

In Equations (7) and (8), $Q_{t}(\mathrm{mg} / \mathrm{g})$ and $Q_{e}(\mathrm{mg} / \mathrm{g})$ are the amount of dyes adsorbed in time $t(\mathrm{~min})$ and at equilibrium, respectively; $K_{1}$ and $K_{2}$ are the speed constants of pseudo-first-order $\left(\mathrm{min}^{-1}\right)$ and pseudo-second-order (g.mg. $\mathrm{min}^{-1}$ ), respectively.

\section{Results and Discussion}

\subsection{Characterization of Natural and Activated Clays}

Table 1 shows the chemical analysis obtained from the RF, RF1, and RF2 clays. As expected, $\mathrm{SiO}_{2}$ and $\mathrm{Al}_{2} \mathrm{O}_{3}$ were the major mineral constituents both for natural clay and for clays activated with the acids $\mathrm{HCl}$ and $\mathrm{H}_{2} \mathrm{SO}_{4}$. The components $\mathrm{MgO}$ and $\mathrm{Fe}_{2} \mathrm{O}_{3}$ were also identified in small amounts in the RF, RF1 and RF2 clays; however, the $\mathrm{CaO}$ was identified in the RF and $\mathrm{RF}_{1}$ clays only. It is well known that $\mathrm{Ca}^{2+}$ ions are present in the interlamellar layer, and the $\mathrm{Mg}^{2+}$ and $\mathrm{Fe}^{3+}$ ions are present in the octahedral sheets [58]. These three constituents $\left(\mathrm{CaO}, \mathrm{MgO}\right.$, and $\left.\mathrm{Fe}_{2} \mathrm{O}_{3}\right)$ negatively influence the adsorbent capacity of calcium bentonite because cationic exchanges can be prejudiced. In this regard, the acid attack can increase the adsorbent capacity of calcium bentonite, once the $\mathrm{Ca}^{2+}, \mathrm{Mg}^{2+}$ and $\mathrm{Fe}^{3+}$ ions are decreased (or completely removed). The other oxides were identified to a lesser degree, with percentage values lower than $0.5 \%$.

Table 1. Chemical composition (wt \%) of the samples RF, RF1, and RF2.

\begin{tabular}{ccccccccccccc}
\hline Clays & $\mathrm{SiO}_{2}$ & $\mathrm{Al}_{2} \mathrm{O}_{3}$ & $\mathrm{Fe}_{2} \mathrm{O}_{3}$ & $\mathrm{MgO}$ & $\mathrm{CaO}$ & $\mathrm{TiO}_{2}$ & $\mathrm{RuO}_{2}$ & $\mathrm{~K}_{2} \mathrm{O}$ & $\mathrm{Cr}_{2} \mathrm{O}_{3}$ & $\mathrm{SO}_{3}$ & Others & $\mathrm{LF}^{*}$ \\
\hline $\mathrm{RF}$ & 45.3 & 20.7 & 5.9 & 2.7 & 1.6 & 0.8 & 0.2 & 0.5 & 0.04 & 0.1 & 0.05 & 22.1 \\
$\mathrm{RF} 1$ & 47.8 & 20.5 & 5.7 & 2.2 & 0.2 & 0.8 & - & - & 0.03 & 0.1 & 0.03 & 22.3 \\
$\mathrm{RF} 2$ & 54.2 & 19.1 & 3.3 & 1.7 & - & 0.5 & - & - & - & 1.1 & 0.42 & 19.7 \\
\hline \multicolumn{8}{c}{ * LF: loss of fire. }
\end{tabular}

Additionally, in Table 1, the increase in the amount of $\mathrm{SiO}_{2}$, upon acid attack, is related to the partial destruction of the octahedral layers and the reduction of the components $\mathrm{Al}_{2} \mathrm{O}_{3}, \mathrm{Fe}_{2} \mathrm{O}_{3}, \mathrm{MgO}$ and $\mathrm{CaO}$ in the samples treated with acid. The $\mathrm{Mg}^{2+}, \mathrm{Fe}^{3+}$ and $\mathrm{Ca}^{2+}$ ions have a high rate of dissolution in the $\mathrm{HCl}$ and $\mathrm{H}_{2} \mathrm{SO}_{4}$ acids, being this rate higher in $\mathrm{H}_{2} \mathrm{SO}_{4}$ [59]. For this reason, the decrease of such ions was more marked in the sample RF2. In the sample RF2, the attack with $\mathrm{H}_{2} \mathrm{SO}_{4}$ thoroughly 
removed the $\mathrm{CaO}$. This behavior is related to the fact that the $\mathrm{Ca}^{2+}$ ions in polycationic clays are easily dissolved by the protons, due to being located in the interlamellar space of calcium bentonite [60]. Additionally, potential carbonates and calcite are also naturally dissolved in acid environments.

Figure 1 shows diffractograms obtained from the samples RF, RF1, and RF2. The crystalline phases identified were smectite (JCPDS 13-0135), quartz (JCPDS 46-1045), kaolinite (JCPDS 78-2110), and calcite (JCPDS 84-0710). Based on the qualitative analysis, we can note that the acid treatment resulted in a decrease in the intensity of peaks in the samples RF1 and RF2 [60]. The decreased intensity of the montmorillonite main peak indicates that there was a partial destruction and rearrangement of the ions in the tetrahedral and octahedral layers of the clays [61-63].

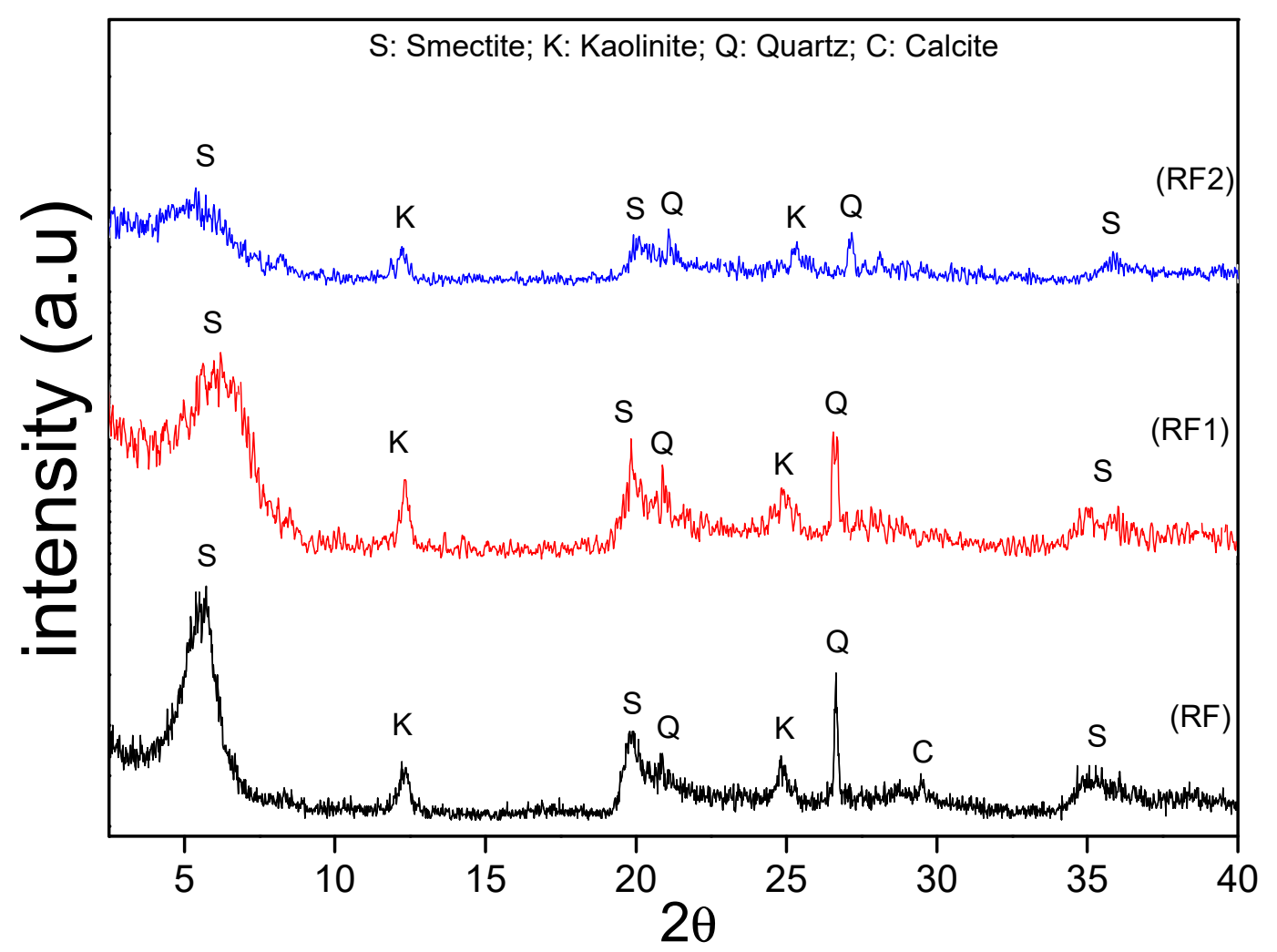

Figure 1. X-ray diffractograms obtained from the RF, RF1, and RF2 clays.

Figure 2a,b shows the DTA and TG curves of the RF, RF1, and RF2 clays. Figure 2a shows the DTA curves; in general, the curves show three thermal events. The first thermal event has an endothermic nature, and the peak maximum temperatures were $146.8^{\circ} \mathrm{C}, 143.8^{\circ} \mathrm{C}$, and $141.8^{\circ} \mathrm{C}$ for the $\mathrm{RF}$, RF1 and RF2 clays, respectively. This first event is related to the evaporation of water (free, adsorbed, and coordinated) [64]. Still, on the first thermal event, we can see a shoulder (more evident in the RF clay, $200^{\circ} \mathrm{C}$ to $280^{\circ} \mathrm{C}$ ), which is often associated with polycationic bentonite with more than one exchangeable cation, such as calcium and magnesium, [65]. The second event was endothermic as well and is related to the partial dehydroxylation of the octahedral sheet of smectite, and the peak maximum temperatures were $569.9{ }^{\circ} \mathrm{C}, 565.0^{\circ} \mathrm{C}$ and $565.9^{\circ} \mathrm{C}$ for the RF, RF1 e RF2 clays, respectively. The third thermal event was exothermic and is related to mullite nucleation [66], and the peak maximum temperatures were $930.0^{\circ} \mathrm{C}, 921.0^{\circ} \mathrm{C}$, and $917.0^{\circ} \mathrm{C}$ for the RF, RF1 e RF2 clays, respectively. There were no significant differences in the intensities of the thermal events in Figure 2a. This behavior indicates that acid treatment did not cause expressive destruction in the crystalline reticulate of the clay minerals found in bentonite. However, the acid activation enabled protonation in the structure of the material, creating acid sites and removing impurities with partial destruction of the crystalline reticulate through dehydroxylation of the structural hydroxyl groups present in the octahedral layer of the clay $[67,68]$. 

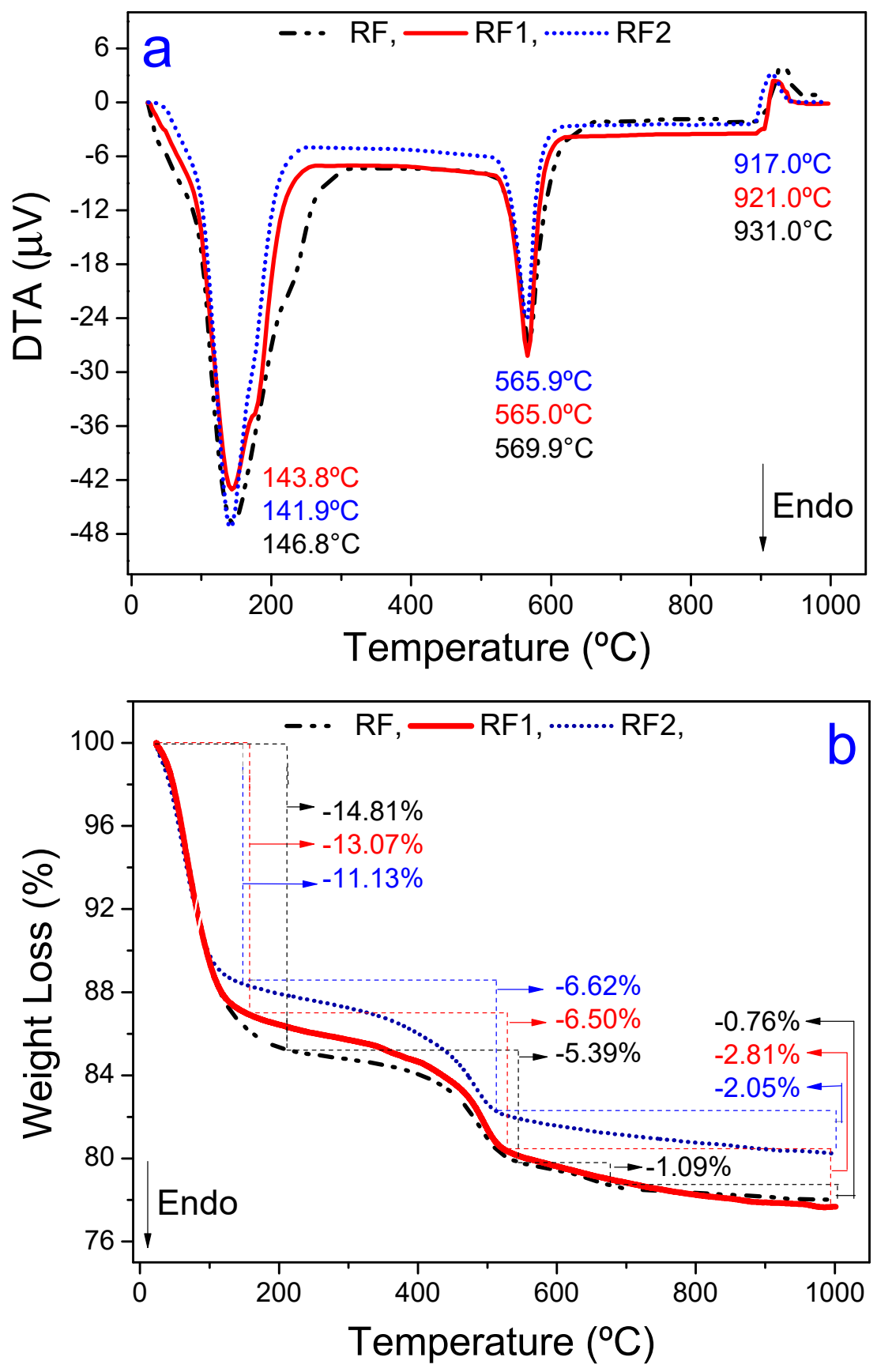

Figure 2. Shows DTA (a) and TG (b) curves measured from the RF, RF1, and RF2 clays.

Figure $2 b$ shows TG curves in which losses of mass could be found concerning the thermal events showed in the DTA curves (see Figure 2a). Therefore, the most marked losses of mass occurred in the first thermal event, and they were $14.81 \%, 13.07 \%$, and $11.13 \%$ for RF, RF1, and RF2, respectively. This behavior indicates that the hydroxyl groups are leaving more efficiently [43]. The losses of mass related to the second thermal event were $5.39 \%, 6.62 \%$ and $6.50 \%$ for the RF, RF1 and RF2 clays, respectively. For the RF clay only, a mass loss of $1.09 \%$ was identified at $\sim 648{ }^{\circ} \mathrm{C}$, which is related to the calcium carbonate decomposition. This thermal event was not seen in the other clays (RF1 and RF2), because the acid attack significantly removed the amount of $\mathrm{CaO}(0.22 \mathrm{wt} \%$ and $0.0 \mathrm{wt}$. \% for the RF1 and RF2 clays, respectively). In the last thermal event, the mass losses were $0.76 \%, 2.05 \%$, and $2.81 \%$ for the RF, RF1, and RF2 samples. The total mass losses measured were $22.05 \%, 22.38 \%$, and $19.80 \%$ for the RF, RF1, and RF2 clays, respectively. 
Figure 3 shows the size distribution of the particle of the RF, RF1, and RF2 clays. All the curves showed a bimodal behavior, in which the major concentration of particles was seen between $2 \mu \mathrm{m}$ and $20 \mu \mathrm{m}$. The RF1 sample showed a higher fraction of particles with a diameter smaller than $2 \mu \mathrm{m}$ when compared to the RF and RF2 samples. In general, the largest average diameter of particles was seen for the samples with acid activation, results also observed by $[67,69]$. This behavior can be related to the likely increase in material porosity after acid activation and to the creation of specific charge sites in the clay surface that favor the electrostatic attraction between the small particles of the clays, generating small agglomerates, which are observed as large particles in the particle size determination test. The lower fraction of particles with a small diameter than $2 \mu \mathrm{m}$ of RF2 can be related to this charge characteristic $[70,71]$. Table 2 summarizes the granulometric compositions and average size of particles.
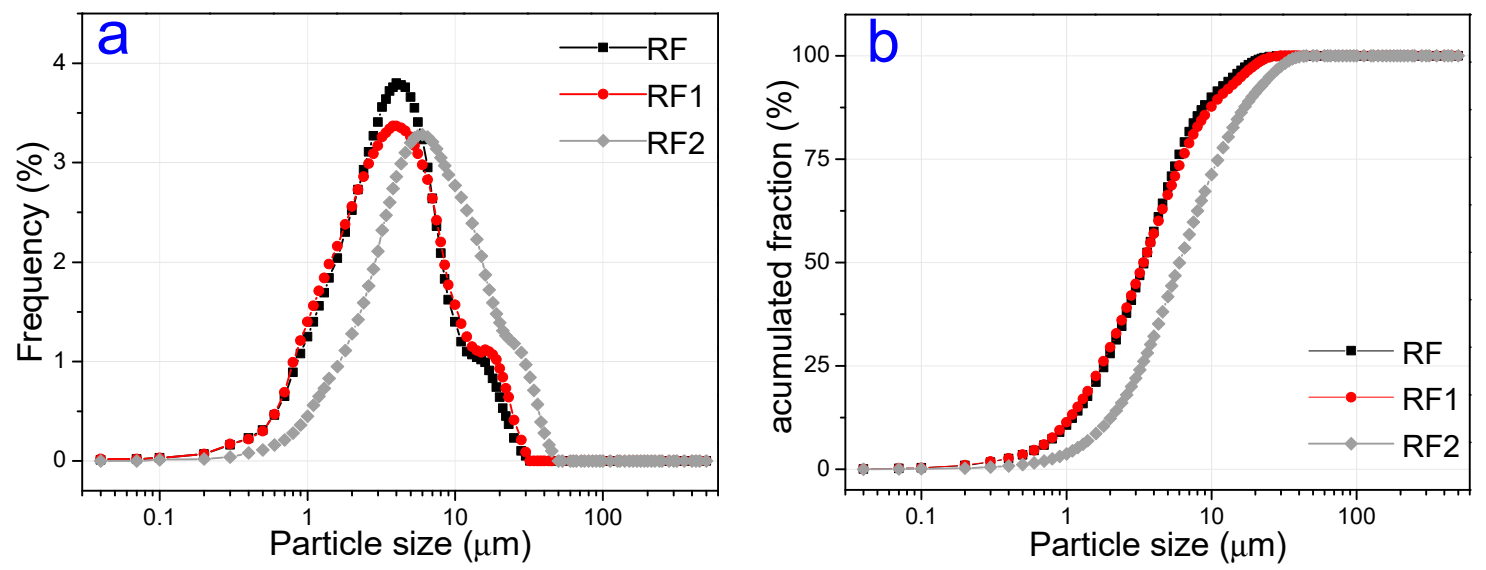

Figure 3. Granulometric analysis of the clays: (a) Frequency, and (b) cumulative values.

Table 2. Granulometric compositions and average sizes of particles measured from the RF, RF1, and RF2 samples.

\begin{tabular}{ccccc}
\hline Samples & $\mathbf{D}<\mathbf{2} \boldsymbol{\mu m}$ & $(\mathbf{2} \boldsymbol{\mu m}<\mathbf{D}<\mathbf{2 0} \boldsymbol{\mu m})$ & $\mathbf{D}>\mathbf{2 0} \boldsymbol{\mu m}$ & Average Diameter $(\boldsymbol{\mu m})$ \\
\hline RF & $27.98 \%$ & $70.77 \%$ & $1.25 \%$ & $4.66 \%$ \\
RF1 & $29.55 \%$ & $68.31 \%$ & $2.14 \%$ & $4.96 \%$ \\
RF2 & $12.31 \%$ & $75.37 \%$ & $8.92 \%$ & $8.46 \%$ \\
\hline
\end{tabular}

\subsection{Adsorption Tests}

Figure $4 \mathrm{a}, \mathrm{b}$ shows the adsorbed amount dependency of the MO and MB dyes due to different initial concentrations of the adsorbate. In general, it was noted that the amount adsorbed $\left(Q_{e}\right)$ of $\mathrm{MO}$ and $\mathrm{MB}$ increases as the initial concentration increases [43]. At a molecular scale, this behavior occurs because the $C_{i}$ increase causes more interactions between the clay surface and the dye molecules, implying a rise in the adsorption rate [72]. Additionally, the increased adsorption rate can be explained due to the increase of charge of the adsorbent in terms of the elevated driving force to transfer the existing mass in greater concentrations of dye [73]. In Figure $4 a$, an increase in $Q_{e}$ can be seen for the clays treated with acid. Indeed, for the MO dye, the acid activation increased the adsorption capacity of the clays in up to $8000 \%$, with increased value of $2.2 \mathrm{mg} / \mathrm{g}$ in the RF, for $67.4 \mathrm{mg} / \mathrm{g}$ in the RF1 and $47.8 \mathrm{mg} / \mathrm{g}$ in the RF2. It is known that the calcium bentonite, such as the other clays, has a negative charge in its surface structure that derives from isomorphic substitutions of the $\mathrm{Al}^{3+}$ for $\mathrm{Si}^{4+}$ ions in the tetrahedral layer, and $\mathrm{Mg}^{2+}$ for $\mathrm{Al}^{3+}$ ions in the octahedral layer [74]. For this reason, the maximal $\mathrm{MO}$ adsorption in RF was insufficient due to the electrostatic repulsion between the negative charge in the clay surface and the negative nature of the MO.

The acid attack creates Brönsted acid sites (positive nature) in the clay surface that are generated by the exchange of cations existing in interlamellar layers $\left(\mathrm{Ca}^{2+}\right.$ and $\left.\mathrm{Mg}^{2+}\right)$ by protons derived from 
the acid [67], and these sites created attract methyl orange molecules (anionic nature) more efficiently and exchange reactions occur. Another effect that also occurs is the removal of $\mathrm{Al}^{3+}$ ions from the octahedral layers and the increase of the clay mineral surface area [43]. These behaviors can be ratified by the decrease of the $\mathrm{CaO}, \mathrm{MgO}$, and $\mathrm{Al}_{2} \mathrm{O}_{3}$ components upon acid attack (see Table 1).
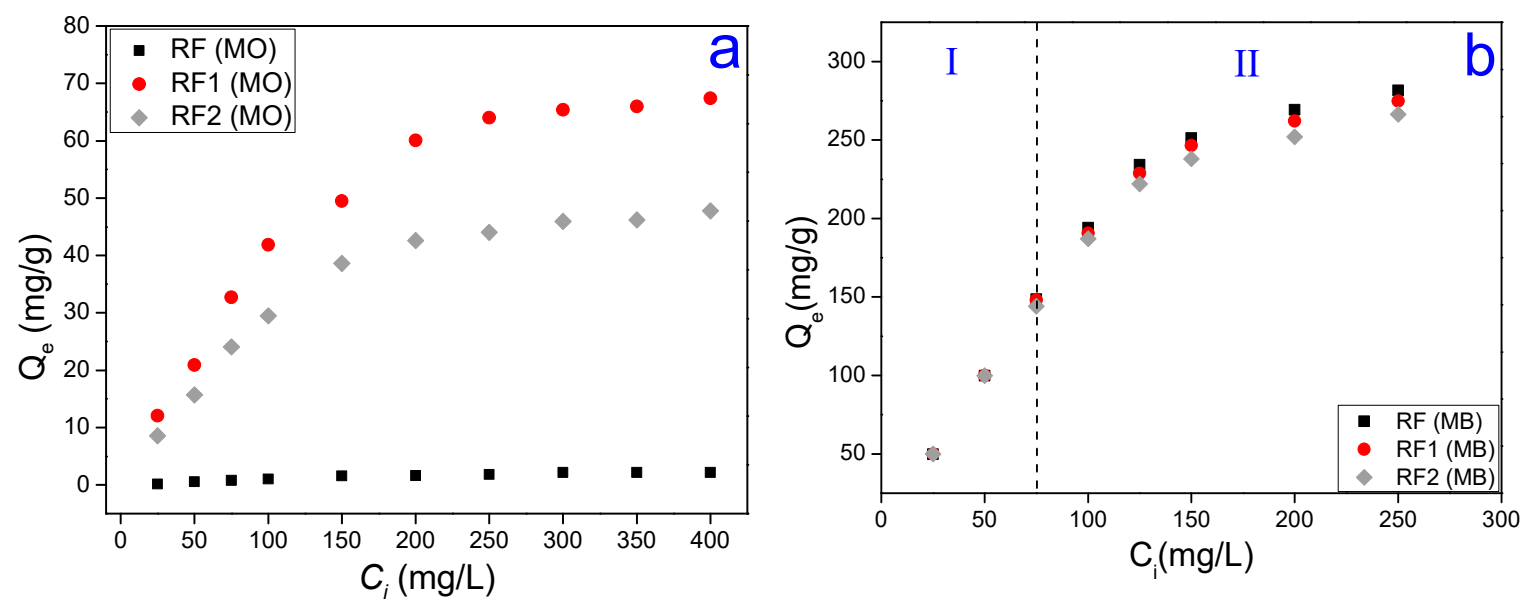

Figure 4. The amounts adsorbed of the MO (a) and MB (b) dyes for different initial concentrations of the adsorbate.

Figure $4 \mathrm{~b}$ can be divided into two regions, where region I is included in the rate of $25 \mathrm{mg} / \mathrm{L}$ and $75 \mathrm{mg} / \mathrm{L}$ of the $C_{i}$. In this region, both the natural clay (RF) and the clays activated with $\mathrm{HCl}$ and $\mathrm{H}_{2} \mathrm{SO}_{4}$ acids (RF1 and RF2, respectively) adsorbed the same amount of the MB dye. As to region II, consisting of the rates $76 \mathrm{mg} / \mathrm{L}$ and $250 \mathrm{mg} / \mathrm{L}$ of $C_{i}$, it was noted that for the RF1 and RF2 clays the $Q_{e}$ values were slightly lower than for the RF clay, having $Q_{\max }^{\exp }$ of $281.7 \mathrm{mg} / \mathrm{g}(\mathrm{RF}), 274.7 \mathrm{mg} / \mathrm{g}$ (RF1) and $266.3 \mathrm{mg} / \mathrm{g}$ (RF2). The MB cationic dye adsorption derives from electrostatic forces arising between the negative charge of the clay and the positive nature of the MB [75]. Therefore, according to the region II (Figure $4 \mathrm{~b}$ ), in the acid-activated clays, as the dye concentration increased, there was also an increase of $Q_{e}$. The slight difference of the amount adsorbed between the acid bentonites and RF, although not statistically representative, can be attributed to the fact of electrostatic interactions are more intense in the natural clay for having more negative sites in its surface.

Comparing Figure $4 \mathrm{a}, \mathrm{b}$, for all the $C_{i}$ values, we can see that the $Q_{e}$ values of the MO dye is much higher in the acid-activated bentonite than natural bentonite. As for the MB dye, no significant differences were seen between the amounts adsorbed by the RF, RF1 and RF2 clays. This confirms the fact that the acid treatment is efficient in calcium bentonites for adsorption of anionic dyes. This could be explained in terms of the electrostatic interaction between the clay and adsorbate, once it had been determined that the acid attack generates Brönsted acid sites, which more easily attract the methyl orange molecules (anionic nature), and these new, more active sites repel the cationic nature of dyes, which explains why the acid treatment was not effective on the clay for adsorption of the MB dye, showing statistically similar RF, RF1 and RF2 results.

It is well known that sulfuric acid can generate a high removal of the octahedral $\mathrm{Al}^{3+}$ ions, an increase in the Si-OH bonds, and the formation of a high amount of amorphous silica phase [71,76]. These phenomena will favor the development of negative charges on the surface of the clay minerals. The $\mathrm{HCl}$ also attacks the structure of the clay mineral but in a lower amount, preventing the natural adsorptive properties of montmorillonite clay from being destroyed. According to Figure $4 \mathrm{a}$, it can be seen that the acid attack was more effective for $\mathrm{HCl}$ acid, previous studies $[77,78]$ have already shown that the activity of hydrochloric acid for pollutant adsorption is higher in clays when compared to sulfuric acid in the same normality. This will favor a higher degree of adsorption of the anionic dyes in $\mathrm{HCl}$ treated samples. 
Figure $5 \mathrm{a}, \mathrm{b}$ relates the adsorbed amounts of the $\mathrm{MO}$ and MB dyes in times set $\left(t_{c}\right)$ in the RF, $\mathrm{RF} 1$ and RF2 samples, fixing $C_{i}$ at $50 \mathrm{mg} / \mathrm{L}$. For Figure $5 \mathrm{a}$, the values of $Q_{e}$ obtained for the MO were $2.2 \mathrm{mg} / \mathrm{g}$ for RF, $67.4 \mathrm{mg} / \mathrm{g}$ for RF1, and $47.8 \mathrm{mg} / \mathrm{g}$ for RF2. In general, we can see that the kinetics of the RF clay is different from that shown in the acid ones for the experimental conditions investigated, due to not having interaction between the clay and the MO, which resulted in low $Q_{e}$ values. In RF1 and RF2, there was a rapid increase in the amount of dye adsorbed in the clay at the initial part of the curve, i.e., the kinetics was higher in the activated clays. This occurs because there is a higher concentration of active sites available in the clay during the initial part of the experiment. Over time, there was a decrease in the concentration of sites available until it reaches equilibrium. The equilibrium is represented from the moment when the amount adsorbed did not vary significantly, i.e., the clay surface is saturated by the dye. The equilibrium times measured for the MO dye were $120 \mathrm{~min}$ for all the clays studied. As to the MB dye (Figure $5 b$ ), the $Q_{e}$ values were the same for all the clays studied at about $100 \mathrm{mg} / \mathrm{g}$, and the kinetic behavior did not vary significantly with the acid treatment in the cationic dye. The equilibrium times were $30 \mathrm{~min}, 45 \mathrm{~min}, 90 \mathrm{~min}$ for the RF, RF1, and RF2 clays, respectively. The major equilibrium time seen in the acid-activated samples were possibly due to the creation of new active sites in the clay [74]. The equilibrium times found in this work are in accordance with those found in the literature $[39,79,80]$.
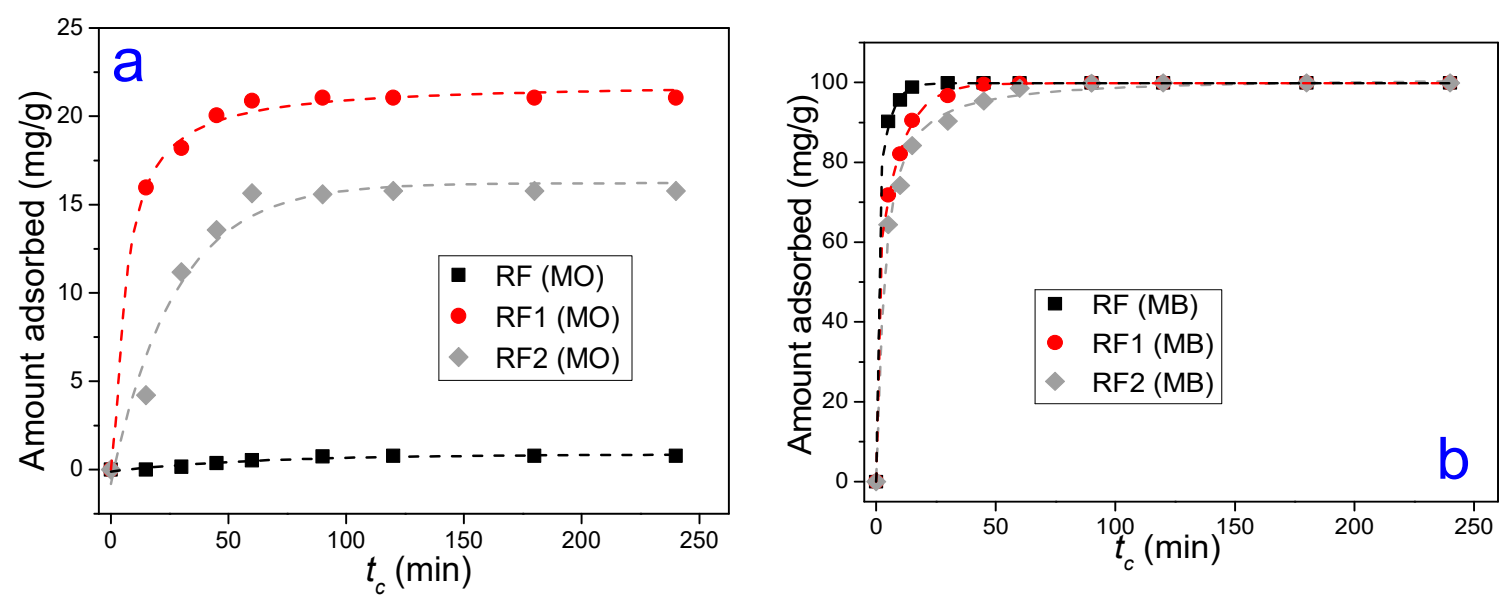

Figure 5. Effect of contact time $\left(t_{c}\right)$ on (a) MO adsorption and (b) MB adsorption. The lines are only guides for the eyes.

Figures 6 and 7a-c show adsorption isotherms obtained for the MO and MB dyes, respectively. For the MO dye (Figure 6), the adsorbent amount and $t_{c}$ were $100 \mathrm{mg}$ and $120 \mathrm{~min}$, respectively. For the MB dye (Figure 7), the amount of adsorbent used was equal to $100 \mathrm{mg}$ for $t_{c}$ of $90 \mathrm{~min}$, respectively. All the experiments were conducted at room temperature. The $Q_{\text {max }}^{\text {calc }}$ values, the $\mathrm{n}$ parameters $\left(\mathrm{n}_{\mathrm{F}}, \mathrm{n}_{\mathrm{DA}}\right.$, $\mathrm{n}_{\mathrm{S}}$ ), and adsorption capacity constants $\left(\mathrm{K}_{\mathrm{L}}, \mathrm{K}_{\mathrm{F}}, \mathrm{K}_{\mathrm{DR}}, \mathrm{K}_{\mathrm{DA}}\right.$ e $\left.\mathrm{K}_{\mathrm{S}}\right)$ were evaluated by the Langmuir, Freundlich, Dubinin-Radushkevich, Dubinin-Astakhov, and Sips models.

The results of the mathematical adjustments implemented in Figures 6 and $7 \mathrm{a}-\mathrm{c}$ are summarized in Table 3. From the MO experimental data, it was possible to see that the best correlation coefficients were obtained from Sips and D-A equations (acid clays: $\mathrm{R}^{2}>0.99$; natural clay: $\mathrm{R}^{2}>0.98$ ). The $Q_{\text {max }}^{\text {calc }}$ values of the MO adsorbates, inferred from the Sips equation, were closer to those measured experimentally in Figure 6. As previously mentioned, the $Q_{\max }^{\exp }$ values measured in this work were $2.2 \mathrm{mg} / \mathrm{g}, 67.4 \mathrm{mg} / \mathrm{g}$ and $47.8 \mathrm{mg} / \mathrm{g}$ for the RF, RF1 and RF2 clays, respectively. Additionally, the error values are also lower for the Sips equation, indicating that this is the modeling that best describes the process of adsorption for MO in these adsorbents. Related the cationic dye studied (methylene blue), the results of Table 3 are in agreement with the experimental results in Figure 7a-c since both showed that the adsorption capacity did not change significantly, i.e., the acid attack was not efficient for improving the sorption of the cationic dye in the calcium bentonites investigated. 


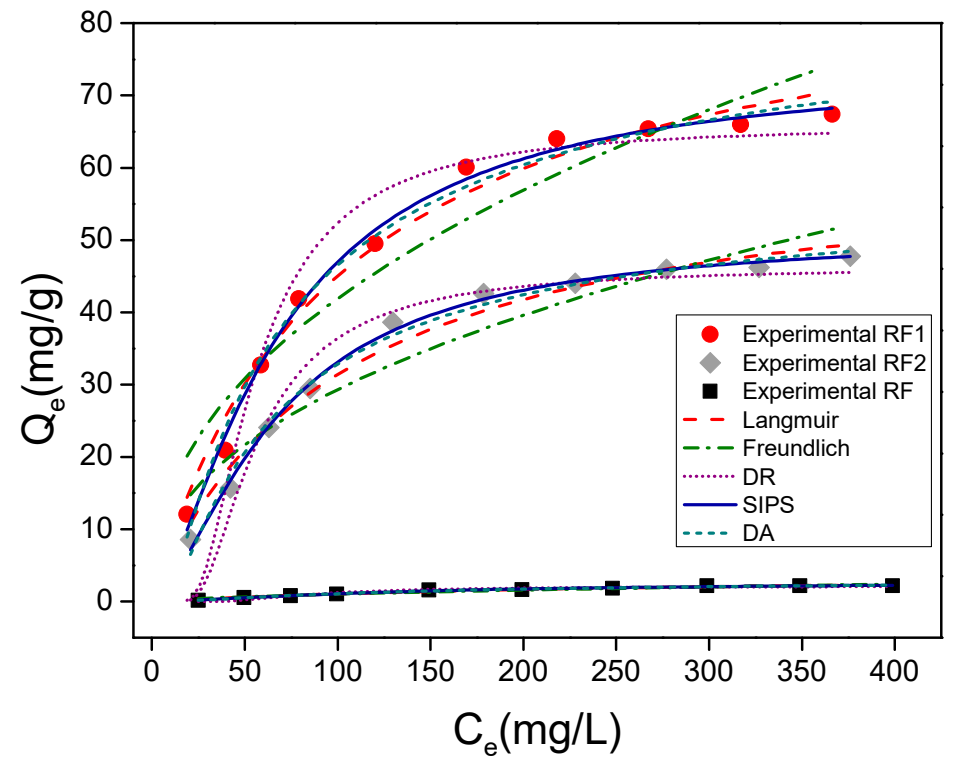

Figure 6. Adsorption isotherms of $\mathrm{MO}$ in room temperature conditions, adsorbent mass $100 \mathrm{mg}$, fixating $t_{c}$ in $120 \mathrm{~min}$.
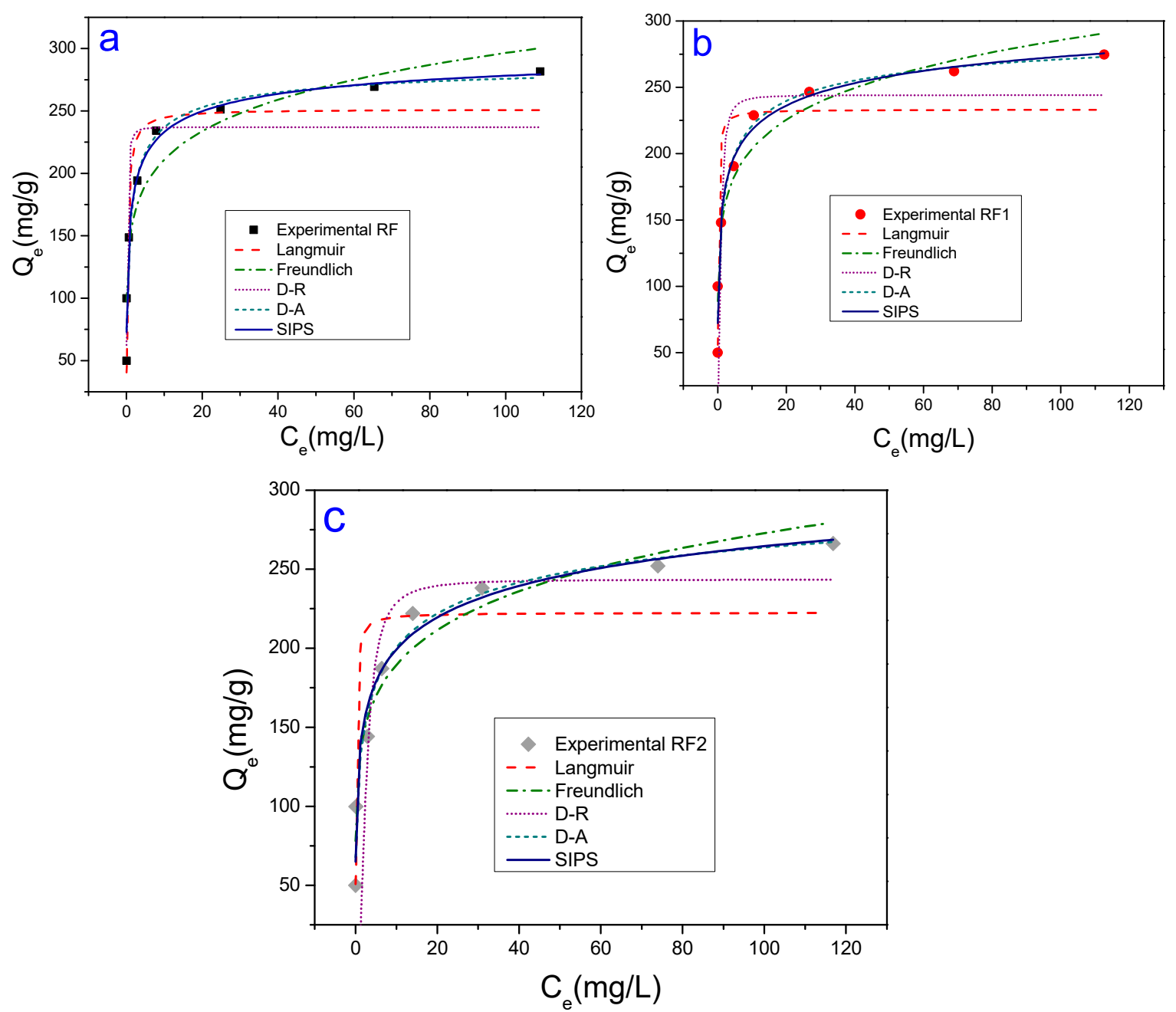

Figure 7. Adsorption isotherms of $\mathrm{MB}$ in room temperature conditions, adsorbent mass $100 \mathrm{mg}$, using $t_{\mathcal{C}}$ in 90 min: (a) adsorbent RF; (b) adsorbent RF1; and (c) adsorbent RF2. 
Table 3. Parameters of MO and MB adsorption isotherms.

\begin{tabular}{|c|c|c|c|c|c|c|c|}
\hline \multirow{2}{*}{ Models } & \multirow{2}{*}{ Parameters } & \multicolumn{3}{|c|}{ Methyl Orange } & \multicolumn{3}{|c|}{ Methylene Blue } \\
\hline & & RF & RF1 & RF2 & $\mathbf{R F}$ & RF1 & RF2 \\
\hline \multirow{5}{*}{ Langmuir } & $\mathrm{Q}_{\mathrm{max}}^{\max }(\mathrm{mg} / \mathrm{g})$ & 3.84 & 89.48 & 62.34 & 251.4 & 233.3 & 222.5 \\
\hline & Error & 0.41 & 4.54 & 3.01 & 16.57 & 17.31 & 16.46 \\
\hline & $\mathrm{K}_{\mathrm{L}}(\mathrm{L} / \mathrm{mg})$ & $3.8 \times 10^{-3}$ & $1.0 \times 10^{-2}$ & $1.0 \times 10^{-2}$ & 3.62 & 8.89 & 7.98 \\
\hline & Error & $7.9 \times 10^{-4}$ & $1.4 \times 10^{-3}$ & $1.3 \times 10^{-2}$ & 1.86 & 5.64 & 4.86 \\
\hline & $\mathrm{R}^{2}$ & 0.975 & 0.976 & 0.977 & 0.840 & 0.761 & 0.753 \\
\hline \multirow{5}{*}{ Freundlich } & $\mathrm{K}_{\mathrm{F}}\left(m \mathrm{~g}^{1-(1 / \mathrm{n})} \mathrm{g}^{-1} \mathrm{~L}^{1 / \mathrm{n}}\right)$ & $5.9 \times 10^{-2}$ & 5.49 & 3.97 & 150.23 & 145.05 & 131.73 \\
\hline & Error & $2.2 \times 10^{-2}$ & 1.74 & 1.26 & 11.78 & 9.85 & 9.11 \\
\hline & $\mathrm{n}_{\mathrm{F}}$ & 1.61 & 2.26 & 2.30 & 6.77 & 6.80 & 6.32 \\
\hline & Error & 0.07 & 0.30 & 0.32 & 1.01 & 0.87 & 0.76 \\
\hline & $\mathrm{R}^{2}$ & 0.945 & 0.908 & 0.904 & 0.904 & 0.933 & 0.950 \\
\hline \multirow{5}{*}{$\mathrm{D}-\mathrm{R}$} & $\mathrm{Q}_{\mathrm{cal}}^{\max }(\mathrm{mg} / \mathrm{g})$ & 2.15 & 65.92 & 46.31 & 237.03 & 244.11 & 243.47 \\
\hline & Error & 0.11 & 2.61 & 1.71 & 17.22 & 23.71 & 23.78 \\
\hline & $\mathrm{K}_{\mathrm{DR}}(\mathrm{KJ} / \mathrm{mol})$ & $9.2 \times 10^{-4}$ & $3.8 \times 10^{-4}$ & $3.9 \times 10^{-4}$ & $2.4 \times 10^{-8}$ & $1.8 \times 10^{--7}$ & $1.1 \times 10^{-6}$ \\
\hline & Error & $1.7 \times 10^{-4}$ & $6.5 \times 10^{-5}$ & $6.6 \times 10^{-5}$ & $8.4 \times 10^{-9}$ & $1.3 \times 10^{-7}$ & $6.9 \times 10^{-7}$ \\
\hline & $\mathrm{R}^{2}$ & 0.928 & 0.926 & 0.932 & 0.768 & 0.602 & 0.617 \\
\hline \multirow{7}{*}{ D-A } & $\mathrm{Q}_{\mathrm{cal}}^{\max }(\mathrm{mg} / \mathrm{g})$ & 3.51 & 86.40 & 58.14 & 294.24 & 311.19 & 347.67 \\
\hline & Error & 0.70 & 7.86 & 4.09 & 22.64 & 38.56 & 74.33 \\
\hline & $\mathrm{K}_{\mathrm{DA}}(\mathrm{KJ} / \mathrm{mol})$ & 6.78 & 4.45 & 4.92 & 0.01 & 0.03 & 0.10 \\
\hline & Error & 1.66 & 0.73 & 0.82 & 0.01 & 0.05 & 0.10 \\
\hline & $\mathrm{n}_{\mathrm{DA}}$ & 0.71 & 0.80 & 0.86 & 0.53 & 0.40 & 0.30 \\
\hline & Error & 0.17 & 0.13 & 0.12 & 0.12 & 0.11 & 0.10 \\
\hline & $\mathrm{R}^{2}$ & 0.985 & 0.986 & 0.988 & 0.964 & 0.962 & 0.961 \\
\hline \multirow{7}{*}{ Sips } & $\mathrm{Q}_{\mathrm{cal}}^{\max }(\mathrm{mg} / \mathrm{g})$ & 2.68 & 74.23 & 51.10 & 314.02 & 353.42 & 403.37 \\
\hline & Error & 0.25 & 2.58 & 1.23 & 33.19 & 72.73 & 139.19 \\
\hline & $\mathrm{K}_{\mathrm{S}}(\mathrm{L} / \mathrm{mmol})$ & $7.7 \times 10^{-4}$ & $2.1 \times 10^{-3}$ & $1.5 \times 10^{-3}$ & 1.07 & 0.76 & 0.50 \\
\hline & Error & $6.8 \times 10^{-4}$ & $1.0 \times 10^{-3}$ & $6.1 \times 10^{-4}$ & 0.32 & 0.33 & 0.28 \\
\hline & $\mathrm{n}_{\mathrm{S}}$ & 1.47 & 1.45 & 1.54 & 0.43 & 0.33 & 0.29 \\
\hline & Error & 0.22 & 0.13 & 0.10 & 0.09 & 0.08 & 0.08 \\
\hline & $R^{2}$ & 0.987 & 0.993 & 0.995 & 0.985 & 0.981 & 0.987 \\
\hline
\end{tabular}

The Sips equation is based on the theory that at low adsorbate concentrations, the adsorption is described by the Freundlich equation. At high adsorbate concentrations, the adsorption is already characterized by the Langmuir equation; that is, it occurs via monolayers [81]. The $\mathrm{K}_{\mathrm{S}}$ adsorption capacity constant obtained from the Sips equation is in agreement with Figure 6 since acid-functionalized calcium bentonite presented higher $\mathrm{K}_{\mathrm{S}}$ values $\left(7.7 \times 10^{-4}, 2.1 \times 10^{-3}\right.$, and $1.5 \times 10^{-3}$ to RF, RF1, and RF2, respectively). On the other hand, the $1 / \mathrm{n}_{\mathrm{S}}$ values, also acquired from the Sips equation, varied between 0.68 and 0.64 . It is known that $1 / \mathrm{n}_{\mathrm{S}}$ values less than 1 , indicating a certain degree of heterogeneity on the surface of the acid-functionalized bentonite [82]. The heterogeneous surface on the acid-functionalized clay occurs because the acid attack disorganizes its structure favoring an increase in the surface area, with consequent formation of mesopores and ions leaching $\mathrm{Ca}^{2+}$ and $\mathrm{Mg}^{2+}$, in the case of this work) $[83,84]$. The experimental evidence for the leaching of $\mathrm{Ca}^{2+}$ and $\mathrm{Mg}^{2+}$ ions can be seen from the analysis in Table 1.

Additionally, the presence of $\mathrm{H}^{+}$ions resulting from the acid protonated the clay surface. Due to this, the adsorption of anionic dye on the acid-functionalized bentonite is likely to occur initially on its surface (more reactive) by an exchange reaction until dye molecules occupy all available sites. Subsequently, the molecules diffuse to the clay layers, continuing the adsorption process through ion exchange reactions. This process suggests the formation of multilayers $[85,86]$.

The adsorption mechanism of the MO and MB dyes to the RF, RF1, and RF2 clays were also investigated from mathematical adjustments performed with the aid of pseudo-first-order and second-order models, Figures 8 and 9. All of the adjustments performed were satisfactory, and the results are summarized in Table 4. 


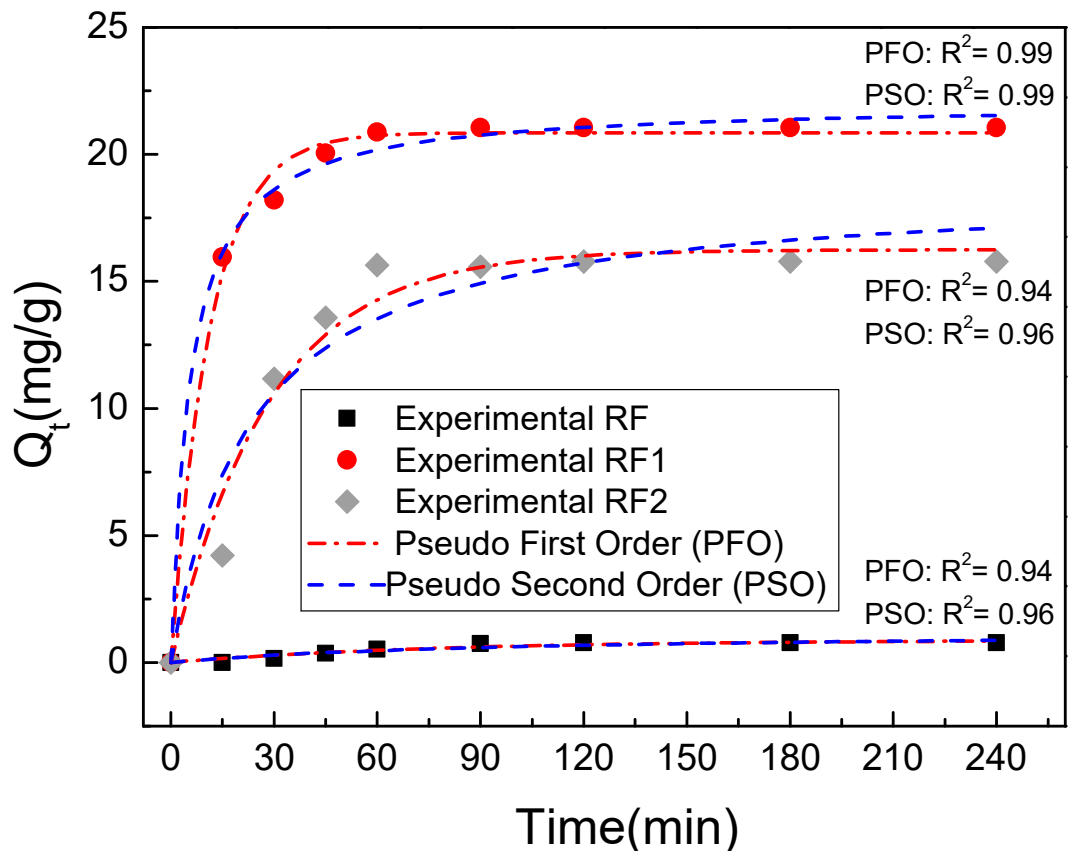

Figure 8. Kinetic graph of $\mathrm{MO}$ in room temperature conditions, adsorbent mass $100 \mathrm{mg}$, fixating $\left(\mathrm{C}_{\mathrm{i}}\right)$ in $50 \mathrm{mg} / \mathrm{L}$.
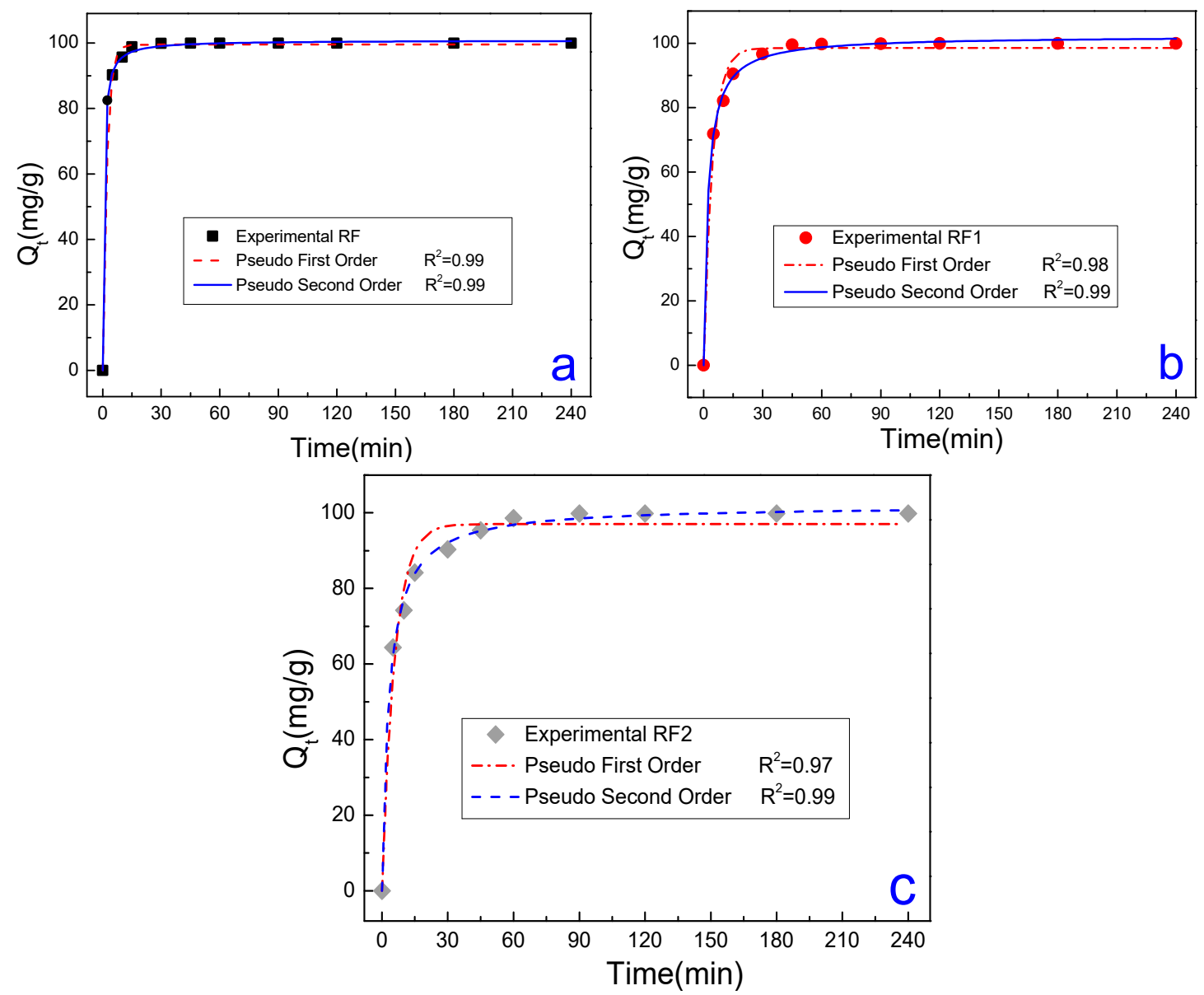

Figure 9. Kinetic graphs of $\mathrm{MB}$ in room temperature conditions, adsorbent mass $100 \mathrm{mg}$, fixating $\mathrm{Ci}$ in 50 mg/L: (a) adsorbent RF; (b) adsorbent RF1; and (c) adsorbent RF2. 
Table 4. Kinetic parameters of MO and MB adsorption.

\begin{tabular}{|c|c|c|c|c|c|c|c|}
\hline \multirow{2}{*}{ Models } & \multirow{2}{*}{ Parameters } & \multicolumn{3}{|c|}{ Methyl Orange } & \multicolumn{3}{|c|}{ Methylene Blue } \\
\hline & & RF & RF1 & RF2 & RF & RF1 & RF2 \\
\hline \multirow{5}{*}{ Pseudo-first-order } & $\mathrm{Q}_{1}(\mathrm{mg} / \mathrm{g})$ & 0.88 & 20.85 & 16.25 & 99.50 & 98.51 & 97.03 \\
\hline & Error & 0.11 & 0.23 & 0.63 & 0.36 & 1.21 & 1.79 \\
\hline & $\mathrm{K}_{1}\left(\mathrm{~min}^{-1}\right)$ & 0.01 & 0.09 & 0.04 & 0.46 & 0.23 & 0.17 \\
\hline & Error & 0.01 & 0.01 & 0.01 & 0.02 & 0.02 & 0.02 \\
\hline & $\mathrm{R}^{2}$ & 0.94 & 0.99 & 0.94 & 0.99 & 0.98 & 0.97 \\
\hline \multirow{5}{*}{ Pseudo-second-order } & $\mathrm{Q}_{2}(\mathrm{mg} / \mathrm{g})$ & 1.23 & 22.02 & 18.76 & 100.80 & 102.28 & 102.03 \\
\hline & Error & 0.27 & 0.26 & 1.53 & 0.30 & 0.59 & 0.76 \\
\hline & $\mathrm{K}_{2}\left(\mathrm{gmin}^{-1} \min ^{-1}\right)$ & $8.3 \times 10^{-3}$ & $8.3 \times 10^{-3}$ & $2.3 \times 10^{-3}$ & $18.4 \times 10^{-3}$ & $9.6 \times 10^{-3}$ & $9.0 \times 10^{-3}$ \\
\hline & Error & $5.8 \times 10^{-3}$ & $1.0 \times 10^{-3}$ & $9.2 \times 10^{-4}$ & $1.61 \times 10^{-3}$ & $2.8 \times 10^{-4}$ & $1.9 \times 10^{-4}$ \\
\hline & $\mathrm{R}^{2}$ & 0.96 & 0.99 & 0.96 & 0.99 & 0.99 & 0.99 \\
\hline
\end{tabular}

From Table 4, we can see that both models, first- and second-order, quantitatively described the $Q_{e}$ values compared the $\mathrm{Q}_{1}$ (first-order equation) and $\mathrm{Q}_{2}$ (second-order equation) values with the $Q_{e}$ values of the MO and MB dyes showed in Figures 8 and 9. However, the pseudo-second-order model showed better $\mathrm{R}^{2}$ values (near 1 ), indicating a better description of the adsorption kinetics. From the concept of this model, it is possible to infer that the limitation rate of the dye molecules adsorption in the clay occurs mainly through chemisorption $[36,37,86,87]$. Therefore, the second-order model is the most indicated to describe the adsorption mechanism, possibly due also to the interaction between the dye molecules and the new sites generated on the surface.

Figure 10 compares $Q_{\text {max }}^{\text {calc }}$ of the MO adsorbed by the RF, RF1 and RF2 clays with the $Q_{\text {max }}^{\text {cal }}$ values by other adsorbents found in the literature. The mathematical adjustment performed by the Sips equation conducted at the MO adsorption isotherm was satisfactory: $\mathrm{R}^{2}=0.987 \mathrm{in} \mathrm{RF}$ and for the activated $R^{2}=0.993$ and $R^{2}=0.995$ for RF1 and RF2, respectively. Therefore, the maximal adsorbed amounts of MO used to construct Figure 10 are those shown in Table 3.

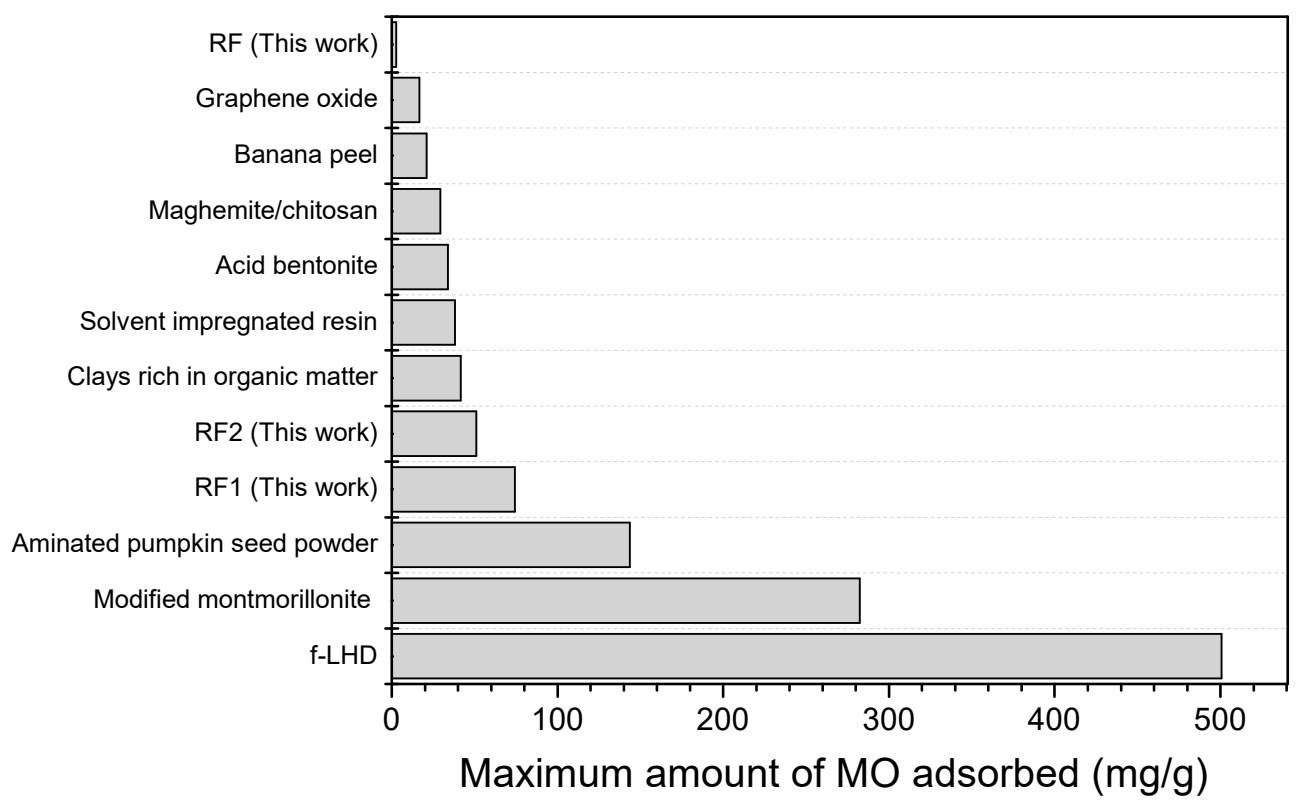

Figure 10. Comparison of $Q_{m a x}^{c a l c}$ of the $\mathrm{MO}$ dye for different adsorbents studied in the literature.

In this regard, Figure 10 compares the $Q_{\max }^{\text {calc }}$ of $\mathrm{MO}$ obtained in this paper with literary data for graphene oxide [31], acid bentonite [88], solvent impregnated resin [89], clays rich in an organic matter [90], banana peel [91], maghemite/chitosan [92], aminated pumpkin seed powder [93], montmorillonite modified by gemini surfactants [94], and layered double hydroxides with flower-like morphology (f-LHD) [95]. In our paper, the RF clay showed the worst $Q_{\text {max }}^{\text {calc }}$ of MO dye. As discussed 
before, this is because the natural clay has a predominantly negative contact surface while the MO dye is anionic. The acid attack applied $Q_{\max }^{\text {calc }}$ of MO (RF1 and RF2) satisfactorily, as it increased the adsorption capacity of the anionic dye and also showed better values compared to those investigated by $[31,88-90,96]$. The adsorbents aminated pumpkin seed powder [93], montmorillonite modified by gemini surfactants [94] and layered double hydroxides with flower-like morphology (f-LHD) [95], showed values of $143.7 \mathrm{mg} / \mathrm{g}, 282.4 \mathrm{mg} / \mathrm{g}$, and $500.6 \mathrm{mg} / \mathrm{g}$, respectively. The authors used adsorbents modified with more complex and expensive techniques that can be difficult to apply, in contrast to that used in this paper.

\section{Conclusions}

The purpose of this paper was to evaluate the efficiency of the acid treatment in Brazilian bentonite for the adsorption of anionic dye methyl orange. The attack with acids did not significantly destructed the structure of the clay minerals found in the clay, with a decrease in the concentration of $\mathrm{Ca}^{2+} \mathrm{Mg}^{2+}$ and $\mathrm{Fe}^{3+}$ ions. It was possible to raise the adsorption capacity of $2.2 \mathrm{mg} / \mathrm{g}$ to $67.4 \mathrm{mg} / \mathrm{g}$ of methyl orange with acid treatment, which is an increase of $8000 \%$ in anionic dye adsorption. The acid activation did not significantly change the clay adsorption capacity in relation to the cationic dye used as a probe, the methylene blue, with the acid clay reaching values of $274.7 \mathrm{mg} / \mathrm{g}$ (RF1) and $266.3 \mathrm{mg} / \mathrm{g}$ (RF2). The bentonite has adsorption based on a heterogeneous surface. Acid activation of the bentonite maximized the adsorption capacity of the anionic dye. However, it did not significantly reduce the adsorption capacity of the cationic dye, making the clay a potentially commercial, sustainable, and eco-friendly material for the treatment of waters contaminated with dyes.

Author Contributions: J.V.F. Data curation and Formal analysis, G.d.A.N. and R.R.M. Conceptualization, Funding acquisition and Project administration, A.M.R. Formal analysis, and Writing-review \& editing. All authors have read and agreed to the published version of the manuscript.

Funding: This research was funded by Coordenação de Aperfeiçoamento de Pessoal de Nível Superior (CAPES), grant number 88882.455332/2019-01.

Acknowledgments: The authors would like to thank all support provided by the Laboratório de Tecnologia dos Materiais, which was essential for the elaboration of this work.

Conflicts of Interest: The authors declare no conflict of interest.

\section{References}

1. Djilani, C.; Zaghdoudi, R.; Djazi, F.; Bouchekima, B.; Lallam, A.; Modarressi, A.; Rogalski, M. Adsorption of dyes on activated carbon prepared from apricot stones and commercial activated carbon. J. Taiwan Inst. Chem. Eng. 2015, 53, 112-121. [CrossRef]

2. Yagub, M.T.; Sen, T.K.; Afroze, S.; Ang, H.M. Dye and its removal from aqueous solution by adsorption: A review. Adv. Colloid Interface Sci. 2014, 209, 172-184. [CrossRef]

3. Errais, E.; Duplay, J.; Darragi, F.; M'Rabet, I.; Aubert, A.; Huber, F.; Morvan, G. Efficient anionic dye adsorption on natural untreated clay: Kinetic study and thermodynamic parameters. Desalination 2011, 275, 74-81. [CrossRef]

4. Bhatti, M.A.; Shah, A.A.; Almani, K.F.; Tahira, A.; Chalangar, S.E.; Chandio, A.D.; Nur, O.; Willander, M.; Ibupoto, Z.H. Efficient photo catalysts based on silver doped $\mathrm{ZnO}$ nanorods for the photo degradation of methyl orange. Ceram. Int. 2019, 45, 23289-23297. [CrossRef]

5. Zhang, W.; Tang, G.; Yan, J.; Zhao, L.; Zhou, X.; Wang, H.; Feng, Y.; Guo, Y.; Wu, J.; Chen, W.; et al. The decolorization of methyl orange by persulfate activated with natural vanadium-titanium magnetite. Appl. Surf. Sci. 2020, 509, 144886. [CrossRef]

6. Calimli, M.H.; Nas, M.S.; Burhan, H.; Mustafov, S.D.; Demirbas, Ö.; Sen, F. Preparation, characterization and adsorption kinetics of methylene blue dye in reduced-graphene oxide supported nanoadsorbents. J. Mol. Liq. 2020, 309, 113171. [CrossRef]

7. Cai, B.; Feng, J.F.; Peng, Q.Y.; Zhao, H.F.; Miao, Y.C.; Pan, H. Super-fast degradation of high concentration methyl orange over bifunctional catalyst Fe/Fe3C@C with microwave irradiation. J. Hazard. Mater. 2020, 392, 122279. [CrossRef] 
8. Hou, Y.; Yan, S.; Huang, G.; Yang, Q.; Huang, S.; Cai, J. Fabrication of N-doped carbons from waste bamboo shoot shell with high removal efficiency of organic dyes from water. Bioresour. Technol. 2020, 303, 122939. [CrossRef]

9. Azari, A.; Nabizadeh, R.; Nasseri, S.; Mahvi, A.H.; Mesdaghinia, A.R. Comprehensive systematic review and meta-analysis of dyes adsorption by carbon-based adsorbent materials: Classification and analysis of last decade studies. Chemosphere 2020, 250, 126238. [CrossRef]

10. Holkar, C.R.; Jadhav, A.J.; Pinjari, D.V.; Mahamuni, N.M.; Pandit, A.B. A critical review on textile wastewater treatments: Possible approaches. J. Environ. Manag. 2016, 182, 351-366. [CrossRef]

11. Yue, Q.Y.; Gao, B.Y.; Wang, Y.; Zhang, H.; Sun, X.; Wang, S.G.; Gu, R.R. Synthesis of polyamine flocculants and their potential use in treating dye wastewater. J. Hazard. Mater. 2008, 152, 221-227. [CrossRef]

12. Qin, Y.; Wang, L.; Zhao, C.; Chen, D.; Ma, Y.; Yang, W. Ammonium-Functionalized Hollow Polymer Particles As a pH-Responsive Adsorbent for Selective Removal of Acid Dye. ACS Appl. Mater. Interfaces 2016, 8, 16690-16698. [CrossRef]

13. Yuan, D.; Sun, M.; Tang, S.; Zhang, Y.; Wang, Z.; Qi, J.; Rao, Y.; Zhang, Q. All-solid-state BiVO4/ZnIn2S4 Z-scheme composite with efficient charge separations for improved visible light photocatalytic organics degradation. Chin. Chem. Lett. 2020, 31, 547-550. [CrossRef]

14. Kausar, A.; Iqbal, M.; Javed, A.; Aftab, K.; Nazli, Z.I.H.; Bhatti, H.N.; Nouren, S. Dyes adsorption using clay and modified clay: A review. J. Mol. Liq. 2018, 256, 395-407. [CrossRef]

15. Selim, K.A.; Youssef, M.A.; Abd El-Rahiem, F.H.; Hassan, M.S. Dye removal using some surface modified silicate minerals. Int. J. Min. Sci. Technol. 2014, 24, 183-189. [CrossRef]

16. Tran, H.N.; You, S.J.; Chao, H.P. Fast and efficient adsorption of methylene green 5 on activated carbon prepared from new chemical activation method. J. Environ. Manag. 2017, 188, 322-336. [CrossRef]

17. Carvajal-Bernal, A.M.; Gómez-Granados, F.; Giraldo, L.; Moreno-Piraján, J.C.; Balsamo, M.; Erto, A. Kinetic and thermodynamic study of n-pentane adsorption on activated carbons modified by either carbonization or impregnation with ammonium hydroxide. Microporous Mesoporous Mater. 2020, 110196. [CrossRef]

18. Kameda, T.; Horikoshi, K.; Kumagai, S.; Saito, Y.; Yoshioka, T. Adsorption of urea, creatinine, and uric acid onto spherical activated carbon. Sep. Purif. Technol. 2020, 237, 116367. [CrossRef]

19. Partlan, E.; Ren, Y.; Apul, O.G.; Ladner, D.A.; Karanfil, T. Adsorption kinetics of synthetic organic contaminants onto superfine powdered activated carbon. Chemosphere 2020, 253, 126628. [CrossRef]

20. Ma, F.; Gui, Y.; Liu, P.; Xue, Y.; Song, W. Functional fibrous materials-based adsorbents for uranium adsorption and environmental remediation. Chem. Eng. J. 2020, 390, 124597. [CrossRef]

21. Yang, S.; Yin, K.; Wu, J.; Wu, Z.; Chu, D.; He, J.; Duan, J.A. Ultrafast nano-structuring of superwetting Ti foam with robust antifouling and stability towards efficient oil-in-water emulsion separation. Nanoscale 2019, 11, 17607-17614. [CrossRef] [PubMed]

22. Cherifi, Z.; Boukoussa, B.; Mokhtar, A.; Hachemaoui, M.; Zeggai, F.Z.; Zaoui, A.; Bachari, K.; Meghabar, R. Preparation of new nanocomposite poly(GDMA)/mesoporous silica and its adsorption behavior towards cationic dye. React. Funct. Polym. 2020, 214, 104611. [CrossRef]

23. Igberase, E.; Osifo, P.O. Mathematical modelling and simulation of packed bed column for the efficient adsorption of $\mathrm{Cu}$ (II) ions using modified bio-polymeric material. J. Environ. Chem. Eng. 2019, 7, 103129. [CrossRef]

24. Grandclément, C.; Seyssiecq, I.; Piram, A.; Wong-Wah-Chung, P.; Vanot, G.; Tiliacos, N.; Roche, N.; Doumenq, P. From the conventional biological wastewater treatment to hybrid processes, the evaluation of organic micropollutant removal: A review. Water Res. 2017, 111, 297-317. [CrossRef]

25. Nekouei Marnani, N.; Shahbazi, A. A novel environmental-friendly nanobiocomposite synthesis by EDTA and chitosan functionalized magnetic graphene oxide for high removal of Rhodamine B: Adsorption mechanism and separation property. Chemosphere 2019, 218, 715-725. [CrossRef]

26. Chowdhury, S.; Mishra, R.; Saha, P.; Kushwaha, P. Adsorption thermodynamics, kinetics and isosteric heat of adsorption of malachite green onto chemically modified rice husk. Desalination 2011, 265, 159-168. [CrossRef]

27. Juchen, P.T.; Piffer, H.H.; Veit, M.T.; Da Cunha Gonçalves, G.; Palácio, S.M.; Zanette, J.C. Biosorption of reactive blue BF-5G dye by malt bagasse: Kinetic and equilibrium studies. J. Environ. Chem. Eng. 2018, 6, 7111-7118. [CrossRef]

28. Temesgen, F.; Gabbiye, N.; Sahu, O. Biosorption of reactive red dye (RRD) on activated surface of banana and orange peels: Economical alternative for textile effluent. Surf. Interfaces 2018, 12, 151-159. [CrossRef] 
29. De Mattos, N.R.; de Oliveira, C.R.; Camargo, L.G.B.; da Silva, R.S.R.; Lavall, R.L. Azo dye adsorption on anthracite: A view of thermodynamics, kinetics and cosmotropic effects. Sep. Purif. Technol. 2019, 209, 806-814. [CrossRef]

30. Tong, D.S.; Wu, C.W.; Adebajo, M.O.; Jin, G.C.; Yu, W.H.; Ji, S.F.; Zhou, C.H. Adsorption of methylene blue from aqueous solution onto porous cellulose-derived carbon/montmorillonite nanocomposites. Appl. Clay Sci. 2018, 161, 256-264. [CrossRef]

31. Robati, D.; Mirza, B.; Rajabi, M.; Moradi, O.; Tyagi, I.; Agarwal, S.; Gupta, V.K. Removal of hazardous dyes-BR 12 and methyl orange using graphene oxide as an adsorbent from aqueous phase. Chem. Eng. J. 2016, 284, 687-697. [CrossRef]

32. Ji, Y.; Zhong, H.; Chen, P.; Xu, X.; Wang, Y.; Wang, H.; Liu, G. Single and simultaneous adsorption of methyl orange and $\mathrm{p}$-chlorophenol on organo-vermiculites modified by an asymmetric gemini surfactant. Colloids Surf. A Physicochem. Eng. Asp. 2019, 580, 123740. [CrossRef]

33. Şahin, Ö.; Kaya, M.; Saka, C. Plasma-surface modification on bentonite clay to improve the performance of adsorption of methylene blue. Appl. Clay Sci. 2015, 116-117, 46-53. [CrossRef]

34. Sellaoui, L.; Franco, D.; Ghalla, H.; Georgin, J.; Netto, M.S.; Luiz Dotto, G.; Bonilla-Petriciolet, A.; Belmabrouk, H.; Bajahzar, A. Insights of the adsorption mechanism of methylene blue on brazilian berries seeds: Experiments, phenomenological modelling and DFT calculations. Chem. Eng. J. 2020, 394, 125011. [CrossRef]

35. Teich-McGoldrick, S.L.; Greathouse, J.A.; Jové-Colón, C.F.; Cygan, R.T. Swelling Properties of Montmorillonite and Beidellite Clay Minerals from Molecular Simulation: Comparison of Temperature, Interlayer Cation, and Charge Location Effects. J. Phys. Chem. 2015, 119, 20880-20891. [CrossRef]

36. Chaari, I.; Moussi, B.; Jamoussi, F. Interactions of the dye, C.I. direct orange 34 with natural clay. J. Alloys Compd. 2015, 647, 720-727. [CrossRef]

37. Hamza, W.; Dammak, N.; Hadjltaief, H.B.; Eloussaief, M.; Benzina, M. Sono-assisted adsorption of Cristal Violet dye onto Tunisian Smectite Clay: Characterization, kinetics and adsorption isotherms. Ecotoxicol. Environ. Saf. 2018, 163, 365-371. [CrossRef]

38. Bentahar, Y.; Hurel, C.; Draoui, K.; Khairoun, S.; Marmier, N. Adsorptive properties of Moroccan clays for the removal of arsenic(V) from aqueous solution. Appl. Clay Sci. 2016, 119, 385-392. [CrossRef]

39. Bentahar, Y.; Draoui, K.; Hurel, C.; Ajouyed, O.; Khairoun, S.; Marmier, N. Physico-chemical characterization and valorization of swelling and non-swelling Moroccan clays in basic dye removal from aqueous solutions. J. Afr. Earth Sci. 2019, 154, 80-88. [CrossRef]

40. Ren, X.; Zhang, Z.; Luo, H.; Hu, B.; Dang, Z.; Yang, C.; Li, L. Adsorption of arsenic on modified montmorillonite. Appl. Clay Sci. 2014, 97-98, 17-23. [CrossRef]

41. Li, Z.; Chang, P.H.; Jiang, W.T.; Jean, J.S.; Hong, H. Mechanism of methylene blue removal from water by swelling clays. Chem. Eng. J. 2011, 168, 1193-1200. [CrossRef]

42. Da Silva, M.L.; Martins, J.L.; Ramos, M.M.; Bijani, R. Estimation of clay minerals from an empirical model for Cation Exchange Capacity: An example in Namorado oilfield, Campos Basin, Brazil. Appl. Clay Sci. 2018, 158, 195-203. [CrossRef]

43. Kooli, F.; Liu, Y.; Al-Faze, R.; Al Suhaimi, A. Effect of acid activation of Saudi local clay mineral on removal properties of basic blue 41 from an aqueous solution. Appl. Clay Sci. 2015, 116-117, 23-30. [CrossRef]

44. Komadel, P. Acid activated clays: Materials in continuous demand. Appl. Clay Sci. 2016, 131, 84-99. [CrossRef]

45. Foletto, E.L.; Volzone, C.; Morgado, A.F.; Porto, L.M. Influência do tipo de ácido usado e da sua concentração na ativação de uma argila bentonítica. Cerâmica 2001, 47, 208-211. [CrossRef]

46. Moulton, B.J.A.; Rodrigues, A.M.; Sampaio, D.V.; Silva, L.D.; Cunha, T.R.; Zanotto, E.D.; Pizani, P.S. The origin of the unusual DSC peaks of supercooled barium disilicate liquid. CrystEngComm 2019, 21, 2768-2778. [CrossRef]

47. Pereira da Costa, F.; Rodrigues da Silva Morais, C.; Rodrigues, A.M. Sustainable glass-ceramic foams manufactured from waste glass bottles and bentonite. Ceram. Int. 2020. [CrossRef]

48. Soares, V.O.; Rodrigues, A.M. Improvements on sintering and thermal expansion of lithium aluminum silicate glass-ceramics. Ceram. Int. 2020. [CrossRef]

49. De Medeiros, P.S.S.; Lira, H.D.L.; Rodriguez, M.A.; Menezes, R.R.; Neves, G.D.A.; Santana, L.N.D.L. Incorporation of quartzite waste in mixtures used to prepare sanitary ware. J. Mater. Res. Technol. 2019, 8, 2148-2156. [CrossRef] 
50. Santana, L.N.L.; Gomes, J.; Menezes, R.R.; Neves, G.A.; Lira, H.L.; Segadães, A.M. Microstructure development in clays upon heat treatment: Kinetics and equilibrium. Appl. Clay Sci. 2017, 135, 325-332. [CrossRef]

51. Gonçalves, W.P.; Silva, V.J.; Gomes, J.; Menezes, R.R.; Neves, G.A.; Ferreira, H.C.; Santana, L.N.L. Avaliação da influência de diferentes tratamentos térmicos sobre as transformações de fases esmectitas. Cerâmica 2014, 60, 316-322. [CrossRef]

52. Putro, J.N.; Santoso, S.P.; Ismadji, S.; Ju, Y.H. Investigation of heavy metal adsorption in binary system by nanocrystalline cellulose-Bentonite nanocomposite: Improvement on extended Langmuir isotherm model. Microporous Mesoporous Mater. 2017, 246, 166-177. [CrossRef]

53. Kong, Y.; Wang, L.; Ge, Y.; Su, H.; Li, Z. Lignin xanthate resin-bentonite clay composite as a highly effective and low-cost adsorbent for the removal of doxycycline hydrochloride antibiotic and mercury ions in water. J. Hazard. Mater. 2019, 368, 33-41. [CrossRef]

54. Bering, B.P.; Gordeeva, V.A.; Dubinin, M.M.; Efimova, L.I.; Serpinskii, V.V. Development of concepts of the volume filling of micropores in the adsorption of gases and vapors by microporous adsorbents Communication 4. Differential heats and entropies of adsorption. Bull. Acad. Sci. USSR Div. Chem. Sci. 1971, 20,17-22. [CrossRef]

55. Hu, Q.; Zhang, Z. Application of Dubinin-Radushkevich isotherm model at the solid/solution interface: A theoretical analysis. J. Mol. Liq. 2019, 277, 646-648. [CrossRef]

56. Azizian, S. Kinetic models of sorption: A theoretical analysis. J. Colloid Interface Sci. 2004, 276, 47-52. [CrossRef]

57. Ho, Y.S. Review of second-order models for adsorption systems. J. Hazard. Mater. 2006, 136, 681-689. [CrossRef]

58. Chang, W.Z.; Leong, Y.K. Ageing and collapse of bentonite gels-Effects of li, na, k and cs ions. Rheol. Acta 2014, 53, 109-122. [CrossRef]

59. Kooli, F.; Yan, L. Chemical and thermal properties of organoclays derived from highly stable bentonite in sulfuric acid. Appl. Clay Sci. 2013, 83-84, 349-356. [CrossRef]

60. Pentrák, M.; Hronský, V.; Pálková, H.; Uhlík, P.; Komadel, P.; Madejová, J. Alteration of fine fraction of bentonite from Kopernica (Slovakia) under acid treatment: A combined XRD, FTIR, MAS NMR and AES study. Appl. Clay Sci. 2018, 163, 204-213. [CrossRef]

61. Baptiste, B.J.; Esther, N.; Mirela, P.; Richard, K. Adsorption isotherm and kinetics modeling of carotene and free fatty acids adsorption from palm oil onto montmorillonite. Int. J. Biosci. 2013, 6655, 15-24. [CrossRef]

62. Rezende, M.J.C.; Pinto, A.C. Esterification of fatty acids using acid-activated Brazilian smectite natural clay as a catalyst. Renew. Energy 2016, 92, 171-177. [CrossRef]

63. Bieseki, L.; Bertella, F.; Treichel, H.; Penha, F.G.; Pergher, S.B.C. Acid treatments of montmorillonite-rich clay for fe removal using a factorial design method. Mater. Res. 2013, 16, 1122-1127. [CrossRef]

64. Castellini, E.; Malferrari, D.; Bernini, F.; Brigatti, M.F.; Castro, G.R.; Medici, L.; Mucci, A.; Borsari, M. Baseline studies of the clay minerals society source clay montmorillonite stx-1b. Clays Clay Miner. 2017, 65, 220-233. [CrossRef]

65. Santos, P.S. Ciência e Tecnologia de Argilas, 2nd ed.; Edgard Blücher: São Paulo, Brazil, 1992.

66. Morais, I.C.G.; Silva, I.A.; Buriti, B.M.A.B.; Fernandes, J.V.; Silva, D.S.; Neves, G.A.; Ferreira, H.S. Influence of the additivation process on cation exchange capacity and viscosity of bentonitic clay dispersions. Ceramica 2020, 66, 81-87. [CrossRef]

67. Korichi, S.; Elias, A.; Mefti, A.; Bensmaili, A. The effect of microwave irradiation and conventional acid activation on the textural properties of smectite: Comparative study. Appl. Clay Sci. 2012, 59-60, 76-83. [CrossRef]

68. Pálková, H.; Hronský, V.; Jankovič, L.Š.; Madejová, J. The effect of acid treatment on the structure and surface acidity of tetraalkylammonium-montmorillonites. J. Colloid Interface Sci. 2013, 395, 166-175. [CrossRef]

69. Krupskaya, V.V.; Zakusin, S.V.; Tyupina, E.A.; Dorzhieva, O.V.; Zhukhlistov, A.P.; Belousov, P.E.; Timofeeva, M.N. Experimental study of montmorillonite structure and transformation of its properties under treatment with inorganic acid solutions. Minerals 2017, 7, 49. [CrossRef]

70. Angaji, M.T.; Zinali, A.Z.; Qazvini, N.T. Study of Physical, Chemical and Morphological Alterations of Smectite Clay upon Activation and Functionalization via the Acid Treatment. World J. Nano Sci. Eng. 2013, 3, 41006. [CrossRef]

71. Panda, A.K.; Mishra, B.G.; Mishra, D.K.; Singh, R.K. Effect of sulphuric acid treatment on the physico-chemical characteristics of kaolin clay. Colloids Surf. A Physicochem. Eng. Asp. 2010, 363, 98-104. [CrossRef] 
72. Awad, A.M.; Shaikh, S.M.R.; Jalab, R.; Gulied, M.H.; Nasser, M.S.; Benamor, A.; Adham, S. Adsorption of organic pollutants by natural and modified clays: A comprehensive review. Sep. Purif. Technol. 2019, 228, 115719. [CrossRef]

73. Salleh, M.A.M.; Mahmoud, D.K.; Karim, W.A.W.A.; Idris, A. Cationic and anionic dye adsorption by agricultural solid wastes: A comprehensive review. Desalination 2011, 280, 1-13. [CrossRef]

74. Javed, S.H.; Zahir, A.; Khan, A.; Afzal, S.; Mansha, M. Adsorption of Mordant Red 73 dye on acid activated bentonite: Kinetics and thermodynamic study. J. Mol. Liq. 2018, 254, 398-405. [CrossRef]

75. Amari, A.; Gannouni, H.; Khan, M.I.; Almesfer, M.K.; Elkhaleefa, A.M.; Gannouni, A. Effect of structure and chemical activation on the adsorption properties of green clay minerals for the removal of cationic dye. Appl. Sci. 2018, 8, 2302. [CrossRef]

76. Tyagi, B.; Chudasama, C.D.; Jasra, R.V. Determination of structural modification in acid activated montmorillonite clay by FT-IR spectroscopy. Spectrochim. Acta Part A Mol. Biomol. Spectrosc. 2006, 64, 273-278. [CrossRef]

77. Ndé, H.S.; Tamfuh, P.A.; Clet, G.; Vieillard, J.; Mbognou, M.T.; Woumfo, E.D. Comparison of HCl and H2SO4 for the acid activation of a cameroonian smectite soil clay: Palm oil discolouration and landfill leachate treatment. Heliyon 2019, 5, 1-10. [CrossRef]

78. Salawuden, T.O.; Dada, E.O.; Alagbe, S.O. Performance evaluation of acid treated clays for palm oil bleaching. J. Eng. Appl. Sci. 2007, 2, 1677-1680.

79. Elmoubarki, R.; Mahjoubi, F.Z.; Tounsadi, H.; Moustadraf, J.; Abdennouri, M.; Zouhri, A.; El Albani, A.; Barka, N. Adsorption of textile dyes on raw and decanted Moroccan clays: Kinetics, equilibrium and thermodynamics. Water Resour. Ind. 2015, 9, 16-29. [CrossRef]

80. Pawar, R.R.; Lalhmunsiama; Gupta, P.; Sawant, S.Y.; Shahmoradi, B.; Lee, S.M. Porous synthetic hectorite clay-alginate composite beads for effective adsorption of methylene blue dye from aqueous solution. Int. J. Biol. Macromol. 2018, 114, 1315-1324. [CrossRef]

81. Foo, K.Y.; Hameed, B.H. Insights into the modeling of adsorption isotherm systems. Chem. Eng. J. 2010, 156, 2-10. [CrossRef]

82. Papageorgiou, S.K.; Katsaros, F.K.; Kouvelos, E.P.; Nolan, J.W.; Le Deit, H.; Kanellopoulos, N.K. Heavy metal sorption by calcium alginate beads from Laminaria digitata. J. Hazard. Mater. 2006, 137, 1765-1772. [CrossRef]

83. Bastos Andrade, C.G.; Justo, V.F.; Matos, C.M.; Valenzuela, M.G.S.; Volzone, C.; Valenzuela-Diaz, F.R. Evaluation of acid treatment on brown bentonite. In Characterization of Minerals, Metals, and Materials 2015; Springer: Cham, Switzerland, 2015; pp. 735-742. [CrossRef]

84. Vaccari, A. Clays and catalysis: A promising future. Appl. Clay Sci. 1999, 14, 161-198. [CrossRef]

85. Al-Asheh, S.; Banat, F.; Al-Omari, R.; Duvnjak, Z. Predictions of binary sorption isotherms for the sorption of heavy metals by pine bark using single isotherm data. Chemosphere 2000, 41, 659-665. [CrossRef]

86. Toor, M.; Jin, B. Adsorption characteristics, isotherm, kinetics, and diffusion of modified natural bentonite for removing diazo dye. Chem. Eng. J. 2012, 187, 79-88. [CrossRef]

87. Duarte Neto, J.F.; Pereira, I.D.S.; Da Silva, V.C.; Ferreira, H.C.; Neves, D.G.A.; Menezes, R.R. Study of equilibrium and kinetic adsorption of rhodamine B onto purified bentonite clays. Ceramica 2018, 64, 598-607. [CrossRef]

88. Leodopoulos, C.; Doulia, D.; Gimouhopoulos, K.; Triantis, T.M. Single and simultaneous adsorption of methyl orange and humic acid onto bentonite. Appl. Clay Sci. 2012, 70, 84-90. [CrossRef]

89. Wu, Y.; Su, M.; Chen, J.; Xu, Z.; Tang, J.; Chang, X.; Chen, D. Superior adsorption of methyl orange by h-MoS2 microspheres: Isotherm, kinetics, and thermodynamic studies. Dyes Pigments 2019, 170,1-8. [CrossRef]

90. Zayed, A.M.; Abdel Wahed, M.S.M.; Mohamed, E.A.; Sillanpää, M. Insights on the role of organic matters of some Egyptian clays in methyl orange adsorption: Isotherm and kinetic studies. Appl. Clay Sci. 2018, 166, 49-60. [CrossRef]

91. Annadurai, G.; Juang, R.S.; Lee, D.J. Use of cellulose-based wastes for adsorption of dyes from aqueous solutions. J. Hazard. Mater. 2002, 92, 263-274. [CrossRef]

92. Jiang, R.; Fu, Y.-Q.; Zhu, H.-Y.; Yao, J.; Xiao, L. Removal of Methyl Orange from Aqueos Solutions by Magnetic Maghemite/Chitosan Nanocomposite Films: Adsorption Kinetics an Equilibrium. J. Appl. Polym. Sci. 2012, 125, 540-549. [CrossRef] 
93. Subbaiah, M.V.; Kim, D.S. Adsorption of methyl orange from aqueous solution by aminated pumpkin seed powder: Kinetics, isotherms, and thermodynamic studies. Ecotoxicol. Environ. Saf. 2016, 128, $109-117$. [CrossRef]

94. Ren, H.P.; Tian, S.P.; Zhu, M.; Zhao, Y.Z.; Li, K.X.; Ma, Q.; Ding, S.Y.; Gao, J.; Miao, Z. Modification of montmorillonite by Gemini surfactants with different chain lengths and its adsorption behavior for methyl orange. Appl. Clay Sci. 2018, 151, 29-36. [CrossRef]

95. El Hassani, K.; Beakou, B.H.; Kalnina, D.; Oukani, E.; Anouar, A. Effect of morphological properties of layered double hydroxides on adsorption of azo dye Methyl Orange: A comparative study. Appl. Clay Sci. 2017, 140, 124-131. [CrossRef]

96. Lafi, R.; Hafiane, A. Removal of methyl orange (MO) from aqueous solution using cationic surfactants modified coffee waste (MCWs). J. Taiwan Inst. Chem. Eng. 2016, 58, 424-433. [CrossRef]

C 2020 by the authors. Licensee MDPI, Basel, Switzerland. This article is an open access article distributed under the terms and conditions of the Creative Commons Attribution (CC BY) license (http://creativecommons.org/licenses/by/4.0/). 